\title{
Water Preservation and Conservation above Coal Mines Using an Innovative Approach: A Case Study
}

\author{
Yujun $\mathrm{Xu}{ }^{1}$, Liqiang Ma ${ }^{1,2, *(1)}$ and Yihe $\mathrm{Yu}^{1}$ \\ 1 State Key Laboratory of Coal Resources and Mine Safety, School of Mines, China University of Mining and \\ Technology, Xuzhou 221116, China; xyj@cumt.edu.cn (Y.X.); yyhcmsj@cumt.edu.cn (Y.Y.) \\ 2 School of Energy, Xi'an University of Science and Technology, Xi' an 710054, China \\ * Correspondence: ckma@cumt.edu.cn; Tel.: +86-136-4520-1296
}

Received: 9 May 2020; Accepted: 28 May 2020; Published: 2 June 2020

\begin{abstract}
To better protect the ecological environment during large scale underground coal mining operations in the northwest of China, the authors have proposed a water-conservation coal mining (WCCM) method. This case study demonstrated the successful application of WCCM in the Yu-Shen mining area. Firstly, by using the analytic hierarchy process (AHP), the influencing factors of WCCM were identified and the identification model with a multilevel structure was developed, to determine the weight of each influencing factor. Based on this, the five maps: overburden thickness contour, stratigraphic structure map, water-rich zoning map of aquifers, aquiclude thickness contour and coal seam thickness contour, were analyzed and determined. This formed the basis for studying WCCM in the mining area. Using the geological conditions of the Yu-Shen mining area, the features of caved zone, water conductive fractured zone (WCFZ) and protective zone were studied. The equations for calculating the height of the "three zones" were proposed. Considering the hydrogeological condition of Yu-Shen mining area, the criteria were put forward to evaluate the impact of coal mining on groundwater, which were then used to determine the distribution of different impact levels. Using strata control theory, the mechanism and applicability of WCCM methods, including height-restricted mining, (partial) backfill mining and narrow strip mining, together with the applicable zone of these methods, were analyzed and identified. Under the guidance of "two zoning" (zoning based on coal mining's impact level on groundwater and zoning based on applicability of WCCM methods), the WCCM practice was carried out in Yu-Shen mining area. The research findings will provide theoretical and practical instruction for the WCCM in the northwest mining area of China, which is important to reduce the impact of mining on surface and groundwater.
\end{abstract}

Keywords: water protection; water-conservation coal mining (WCCM); influencing factors; "five maps; three zones; and two zoning plans"; water conductive fractured zone (WCFZ)

\section{Introduction}

In China, coal resources are mainly distributed in the north and west, especially in the provinces of Shanxi, Shaanxi, Inner Mongolia, and Xinjiang, which account for about $70 \%$ of all Chinese coal reserves. As the major coal production region, five large coal production bases have been developed in Northwest China, i.e., Shaanbei, Huanglong, Shendong, Ningdong, and Xinjiang (Figure 1). These bases contribute to over one third of China's annual coal production, providing strong support to the country's economic growth [1].

Northwest China has a dry climate and sparse vegetation, hence water resources are scarce, accounting for only $3.9 \%$ of the country's total $[2,3]$. Shallow groundwater, a key water source for local vegetation $[4,5]$, is likely to be affected by mining, making the fragile ecosystems even more vulnerable [6-13]. In the Yu-Shen mining area, in the major production area of the Shaanbei base, 
the groundwater table has declined by more than $15 \mathrm{~m}$ over an area of $306.8 \mathrm{~km}^{2}$ and by $8-15 \mathrm{~m}$ in a further $352.1 \mathrm{~km}^{2}$ area. High intensity mining is found to be the direct cause of significant groundwater table decline in $71.5 \%$ of these areas [11]. It is clear that there are severe conflicts between water scarcity, ecological vulnerability, and coal resources exploitation.

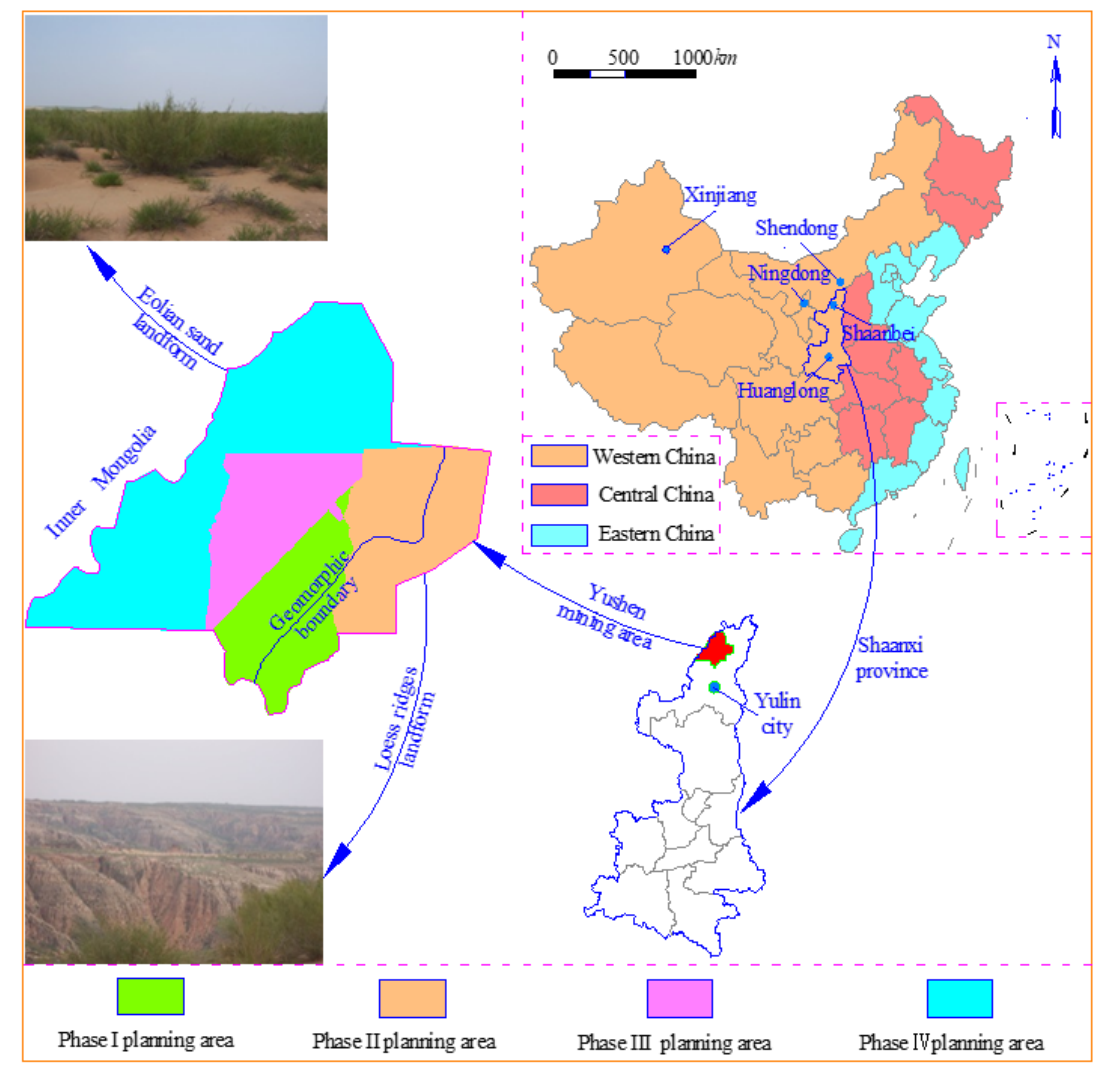

Figure 1. Location and landform of Yu-Shen mining area and five large coal production bases.

Researchers have proposed the concept of water-conservation coal mining (WCCM) and domestic and foreign researchers have conducted in-depth research on mining-induced groundwater loss and WCCM [14-17]. Karaman et al. [18] used a one-dimensional flow equation to examine the effects of subsidence on water-level by introducing a sink that moves with the mining face and tested the validity of this method by estimating parameters of aquifer over a longwall coal mine in the Illinois. Shultz [19] studied the effects of longwall coal mining on the groundwater hydrology of Marshall County (West Virginia, USA). Booth et al. [20] conducted a seven-year study of a sandstone aquifer overlying an active longwall mine in Illinois (USA) and developed a comprehensive model of its influencing factors. They drew the conclusion that the changes of permeability and storativity over the longwall panel caused the decline and recover of the water levels in the sandstone. Hill et al. [21] conducted a field measurement by placing groundwater monitoring networks over the longwall panel. They collected, compiled and analyzed the data to provide documentation of the groundwater fluctuations caused by mining to local officers. Robertson [22] used Ostrom's design principles for common pool resources and revealed several management challenges of the key aquifers' water-level continued declining in the Great Artesian Basin (Australia). Howladar [23] studied the impact of underground coal mining on water environment around the coal mining area in Dinajpur (India). By analyzing the water level data and ground water major parameters collected from 2001 to 2011, he concluded that without a sustainable and long-term coal mining plan in the area, the water level will deplete and the water crisis will occur in the coming day. Gandhe et al. [24] optimized the mining methods and investigated hydrogeology conditions to protect the surface water bodies from being disturbed or destroyed in Godavari (India). 
Fan et al. [25] analyzed the relationship between groundwater table decline and mining intensity in the Yu-Shen mining area based on statistical data of local groundwater table before and after large-scale coal mining. It was found that intensive mining is the primary factor causing the lowering of groundwater table in this area. Based on analysis of the spatial relationship between coal seam, aquifer and aquiclude, Wang et al. [26] divided the study area into several zones according to aquiclude stability after mining and then assessed the applicability of WCCM to different zones. Miao et al. [27] proposed the concept of water-resisting key strata based on the strata control theory. They also analyzed the mechanical behavior of compound key strata using six different composite beam models. Through stability analysis of water-proof strata overlying a shallow coal seam during mining, Huang et al. [28] investigated the fracture development characteristics above and below the water-resisting strata, and proposed the use of water-resisting strata thickness to mining height ratio as the criterion of water resisting capacity assessment. Zhang et al. [29] identified different types of eco-geological environment in the coal mining areas across Northwest China and analyzed the distribution of mining-induced fractures in aquiclude. Based on the stratigraphic structures in typical coal mines of Northwest China, a technological system of WCCM, taking into account the relationship between bedrock thickness, water-bearing of aquifer, mining methods and parameters, was established. Moreover, Ma [2,12,30-33] et al. investigated the development of water conductive fractures induced by shallow seam mining and proposed two WCCM methods. One is applicable for shortwall mining with "mining while filling", and the other is for longwall mining with partial backfilling.

After years of research and practice, WCCM theory and technology have been well-developed and successfully applied in many coal mines of North China and other parts of the world [15,34-37]. However, due to the heavy dependence of WCCM on site specific geological and hydrogeological conditions, a systematic research approach to achieving WCCM in different mining regions is still needed. In this paper, we analyzed the factors affecting WCCM in Yu-Shen mining area (part of Shaanbei coal production base), and then proposed a systematic WCCM method based on "five maps, three zones, and two zoning plans", which would systematize and standardize WCCM research and practice, providing guidance on how to achieve WCCM in Northwest China. This methodology can then be used to develop WCCM in other coal mining regions in other countries besides China.

\section{Identification of Factors Influencing WCCM}

Previous researchers have investigated factors influencing WCCM from various perspectives by analyzing the relationship between the decline of groundwater table and mining intensity. Adhikary et al. [6] found that the height of the water conductive fractured zone (WCFZ) depended greatly on the working face length, mining height and face advance rate. Wang et al. [26] categorized the spatial relationship between coal seam and aquifer (or aquiclude) into different types based on the thicknesses of overburden, aquifer, and aquiclude. Miao et al. [27] discussed the water-resisting property of compound key strata in overburden with different stratigraphic structures. Huang et al. [28] demonstrated that mining depth, mining height, and the thickness and properties of overburden rock strata are primary factors determining the development of upward and downward fractures in water-resisting strata. Zhang et al. [29] suggested that shallow burial depth and large mining height would result in the greater possibility of both surface water and shallow groundwater loss. In addition, they illustrated the synergistic failure characteristics of aquicludes and adjoining strata from the perspectives of overburden thickness, lithology, and stratigraphic structure. Ma et al. [30-32] categorized the thickness, permeability coefficient and groundwater recharge condition of loose aquifers and proposed an empirical equation to estimate the height of WCFZ.

With different results, these studies focused on various influencing factors, but none of them were comprehensive and systematic. Therefore, this study divided the factors influencing WCCM into three broad categories: engineering geology, hydrogeology and mining method. We then proposed a multilevel model for the comprehensive assessment of these factors, which is summarized in Table 1. 
The importance of each influencing factor was assessed using analytic hierarchy process (AHP). The specific steps of calculating the weights of influencing factors are as follows:

Step 1: Influencing factors determination

$$
U=\left\{u_{1}, u_{2}, \ldots u_{\mathrm{n}}\right\}
$$

where $U$ is the domain of WCCM; $u_{1}, u_{2}, \ldots u_{\mathrm{n}}$ are the influencing factors.

Step 2: Judgment matrix construction

Taking the relative weight evaluation of sub-factors of primary factors of engineering and geological conditions by an expert for example, the judgment matrix are as follows:

$$
W_{B_{1} \sim C}=\left[\begin{array}{ccccc}
1 & 1 & 1 & 3 & 5 \\
1 & 1 & 1 & 3 & 5 \\
1 & 1 & 1 & 3 & 5 \\
1 / 3 & 1 / 3 & 1 / 3 & 1 & 5 \\
1 / 5 & 1 / 5 & 1 / 5 & 1 / 5 & 1
\end{array}\right]
$$

where $W$ is the comparison discriminant matrix.

Step 3: The largest eigenvalue and corresponding eigenvector calculation

The largest eigenvalue $\lambda_{\max }$ of the matrix is 5.154 and the corresponding eigenvector $W=(0.276$, $0.276,0.276,0.124,0.047)$.

Step 4: The consistency test

The consistency was checked by $C R=C I / R I$, where $C R$ is the consistency ratio, $R I$ is average consistency index and $C I$ is the consistency indicator, which is defined as $C I=\left(\lambda_{\max }-n\right) /(n-1)$. If $C R<0.1$, the relative weights are reasonable; otherwise, the judgment matrix needs to be adjusted by redistributing the weights of influencing factors. The $C R$ of the matrix is $0.035<0.1$, indicating the weights distribution is reasonable. The weight of engineering and geological conditions is 0.347 , then $0.347 \times W=(0.096,0.096,0.096,0.043,0.016)$, which is the final weight of the five secondary factors among the primary factors given by the expert.

Many researchers, experts and scholars engaged in WCCM have been invited to evaluate the importance of each influencing factor in the AHP model. The mean values of calculation results of their evaluation are listed in Table 1.

As shown in Table 1, the overburden thickness and type of stratigraphic structure have greater impacts than other engineering geological factors. Among the hydrogeological factors, aquiclude thickness has the greatest impact, followed by aquifer thickness and permeability coefficient. In the category of mining method, the impact of effective mining height is an order of magnitude greater than that of other factors; it is therefore considered as the most important factor in mining method. 
Table 1. Influencing factors and the weights of water-conserving mining.

\begin{tabular}{|c|c|c|c|c|c|c|c|}
\hline \multicolumn{2}{|c|}{ Compound Factor Weight B } & \multicolumn{2}{|l|}{ Sub-Factor Weight C } & \multicolumn{2}{|l|}{ Sub-Factor Weight D } & \multicolumn{2}{|c|}{ Sub-Factor Weight E } \\
\hline \multirow{8}{*}{$\begin{array}{l}\text { 1. Engineering and } \\
\text { geological } \\
\text { conditions B1 }\end{array}$} & \multirow{8}{*}{0.347} & Overburden thickness $\mathrm{C} 1$ & 0.096 & & 0.096 & & 0.096 \\
\hline & & Lithology C2 & 0.070 & & 0.070 & & 0.070 \\
\hline & & Physical and mechanical properties $\mathrm{C} 3$ & 0.080 & & 0.080 & & 0.080 \\
\hline & & \multirow{5}{*}{ Geological structure C5 } & \multirow{5}{*}{0.017} & \multirow{3}{*}{ Faults D1 } & \multirow{3}{*}{0.013} & (1) Fault density E1 & 0.006 \\
\hline & & & & & & (2) Fault length E2 & 0.003 \\
\hline & & & & & & (3) Fault throw index E3 & 0.004 \\
\hline & & & & \multirow{2}{*}{ Folds D2 } & \multirow{2}{*}{0.004} & (1) Fold section coefficient E4 & 0.0022 \\
\hline & & & & & & (2) Fold plane coefficient E5 & 0.0018 \\
\hline \multirow{9}{*}{$\begin{array}{c}2 . \\
\text { Hydrogeological } \\
\text { conditions B2 }\end{array}$} & \multirow{9}{*}{0.539} & \multirow{5}{*}{ Aquifer C6 } & \multirow{5}{*}{0.202} & Recharge D3 & 0.082 & & 0.082 \\
\hline & & & & Thickness D4 & 0.040 & & 0.040 \\
\hline & & & & Permeability coefficient D5 & 0.039 & & 0.039 \\
\hline & & & & Groundwater depth D6 & 0.016 & & 0.016 \\
\hline & & & & Vertically adjacent aquifers water difference D7 & 0.025 & & 0.025 \\
\hline & & \multirow{4}{*}{ Aquiclude C7 } & \multirow{4}{*}{0.337} & Thickness D8 & 0.179 & & 0.179 \\
\hline & & & & Horizon D9 & 0.031 & & 0.031 \\
\hline & & & & (3) Water-physical properties D10 & 0.127 & (2) Expansibility E7 & 0.033 \\
\hline & & & & & & (3) Water sensibilityE8 & 0.023 \\
\hline \multirow{9}{*}{$\begin{array}{l}\text { 3. Mining method } \\
\text { B3 }\end{array}$} & \multirow{9}{*}{0.114} & Mining methods $\mathrm{C} 8$ & 0.019 & & 0.019 & & 0.019 \\
\hline & & \multirow{8}{*}{ Mining parameters $\mathrm{C} 9$} & \multirow{8}{*}{0.095} & Effective mining height D11 & 0.067 & & 0.067 \\
\hline & & & & Working face inclination D12 & 0.0075 & & 0.0075 \\
\hline & & & & Mining depth D13 & 0.0085 & & 0.0085 \\
\hline & & & & Advance velocity D14 & 0.003 & & 0.003 \\
\hline & & & & \multirow{2}{*}{ Working face dimensions D15 } & \multirow{2}{*}{0.003} & (1) Inclination length E9 & 0.002 \\
\hline & & & & & & (2) Strike length E10 & 0.001 \\
\hline & & & & \multirow[b]{2}{*}{ Coal pillar stability D16 } & \multirow[b]{2}{*}{0.006} & (1) Coal pillar sizes E11 & 0.0032 \\
\hline & & & & & & $\begin{array}{l}\text { (2) Coal mechanical } \\
\text { properties E12 }\end{array}$ & 0.0028 \\
\hline Total & 1.0 & Total & 1.000 & Total & 1.0000 & Total & 1.0000 \\
\hline
\end{tabular}




\section{Overview of Yu-Shen Mining Area and Determination of "Five Maps"}

\subsection{Geomorphic Features}

The Yu-Shen mining area is located the north of Yulin City and is the center of the Jurassic coalfield in north Shaanxi. This area contains proven coal reserves greater than 30 billion tons. The area is located between the Mu Us Desert (southeast of Inner Mongolia) and the Loess Plateau within northern of Shaanxi Province, and characterized by eolian sand in the west and loess ridges and hills in the east as shown in Figure 1.

The overall surface elevation varies between 1200-1300 m, and is higher in the northwest and lower in the southeast. This area fits into the moderate-temperate zone with a semi-arid continental monsoon climate. Local water resource is limited and unevenly distributed both spatially and temporally. The average annual rainfall is only about $400 \mathrm{~mm}$, over $70 \%$ of which occurs from July to September, while the average annual evaporation exceeds $1900 \mathrm{~mm}$ [38]. Moreover, the ecological environment of this area is vulnerable to mining, and the early development of coal resources has caused a series of geological and ecological problems [12,25].

\subsection{Geological Characteristics}

The typical stratigraphic column of Yu-Shen mining area and the lithological characteristics are shown in Figure 2. The surface is primarily covered by the Quaternary and Neogene strata, and bedrock outcrops are sporadically distributed in valleys. From oldest to youngest, the strata found in this area include: the Lower Jurassic Fuxian Formation $\left(\mathrm{J}_{1} \mathrm{f}\right)$, the Yan'an $\left(\mathrm{J}_{2} \mathrm{y}\right)$, Zhiluo $\left(\mathrm{J}_{2} \mathrm{z}\right)$, and Anding Formations $\left(\mathrm{J}_{2} \mathrm{a}\right)$ of Middle Jurassic age, and the Lower Cretaceous Luohe Formation $\left(\mathrm{K}_{1} \mathrm{l}\right)$, the Neogene System (N), and the Quaternary System (Q) [26-29,31-37]. 


\begin{tabular}{|c|c|c|c|c|c|}
\hline \multicolumn{3}{|c|}{ Geological age } & \multirow{2}{*}{$\begin{array}{l}\text { Thickness } \\
(\mathrm{m})\end{array}$} & \multirow{2}{*}{ Lithology } & \multirow{2}{*}{ Remark } \\
\hline System & Series & Formation & & & \\
\hline \multirow{3}{*}{ 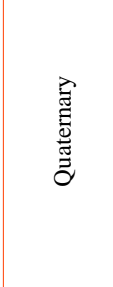 } & Holocene & $\begin{array}{l}\text { Aeolian sand, } \\
\text { Alluvium }\end{array}$ & $0 \sim 149.6$ & $\begin{array}{l}\text { Aeolian sand, } \\
\text { Alluvium }\end{array}$ & Aquifer( I ) \\
\hline & $\begin{array}{c}\text { Upper } \\
\text { Pleistocene }\end{array}$ & Salawusu & $0 \sim 67.3$ & $\begin{array}{l}\text { Fine sandstone, } \\
\text { Medium sandstone }\end{array}$ & Aquifer( II ) \\
\hline & $\begin{array}{l}\text { Middle } \\
\text { Pleistocene }\end{array}$ & Lishi & $0 \sim 109.5$ & $\begin{array}{l}\text { Sandy loam, } \\
\text { Silty clay }\end{array}$ & Aquiclude( I) \\
\hline Neogene & Pliocene & Baode & $0 \sim 170.0$ & $\begin{array}{l}\text { Red clay, } \\
\text { Silty clay }\end{array}$ & Aquiclude( II) \\
\hline Cretaceous & Lower & Luohe & $0 \sim 336.8$ & $\begin{array}{l}\text { Medium sandstone, } \\
\text { Coarse sandstone. }\end{array}$ & Bedrock(I) \\
\hline \multirow{3}{*}{ Jurassic } & \multirow{3}{*}{ Middle } & Anding & $0 \sim 114.0$ & $\begin{array}{l}\text { Sandy mudstone, } \\
\text { Fine sandstone. }\end{array}$ & Bedrock( II ) \\
\hline & & Zhiluo & $0 \sim 134.0$ & $\begin{array}{l}\text { Mudstone, Siltstone, } \\
\text { Sandstone }\end{array}$ & Bedrock(III) \\
\hline & & Yan'an & $150.0 \sim 280.0$ & $\begin{array}{c}\text { Sandstone, Mudstone, } \\
\text { Coal seams }\end{array}$ & $\begin{array}{l}\text { Coal-bearing } \\
\text { strata }\end{array}$ \\
\hline
\end{tabular}

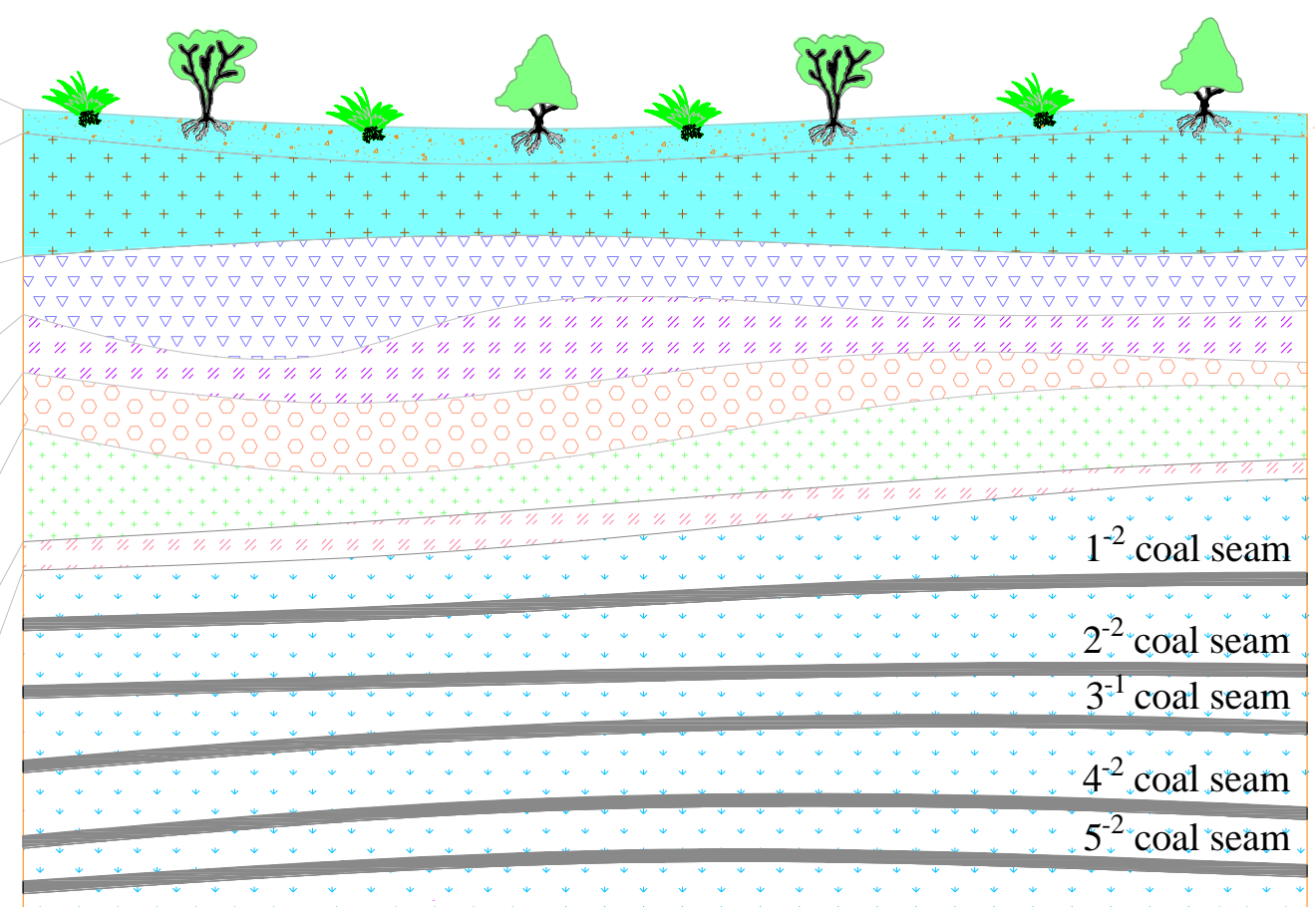

Figure 2. Stratigraphic column in Yu-Shen mining area. 


\subsection{Determination of "Five Maps"}

Five maps were generated for the Yu-Shen mining area based on the relative weights (impacts) presented in Table 1, including: overburden thickness contour, stratigraphic structure map, water-rich zoning map of aquifers, aquiclude thickness contour, and coal thickness contour. These maps were used as the input basic parameters for WCCM.

(1) Overburden thickness contour

The overburden strata of Yu-Shen mining area are dominantly sandstone, mudstone, and sandy mudstone. The overburden thickness ranges generally from $0 \mathrm{~m}$ to $650 \mathrm{~m}$. As a result of intense weathering and erosion, the overburden gradually decreases from northwest to southeast as shown in Figure 3. The roof strata of the coal seams are primarily composed of medium-hard rocks (compressive strength: $20-40 \mathrm{MPa}$ ), such as mudstone with an average UCS (uniaxial compressive strength) of 31.4 MPa and sandstone having an average UCS of $28.9 \mathrm{MPa}$.

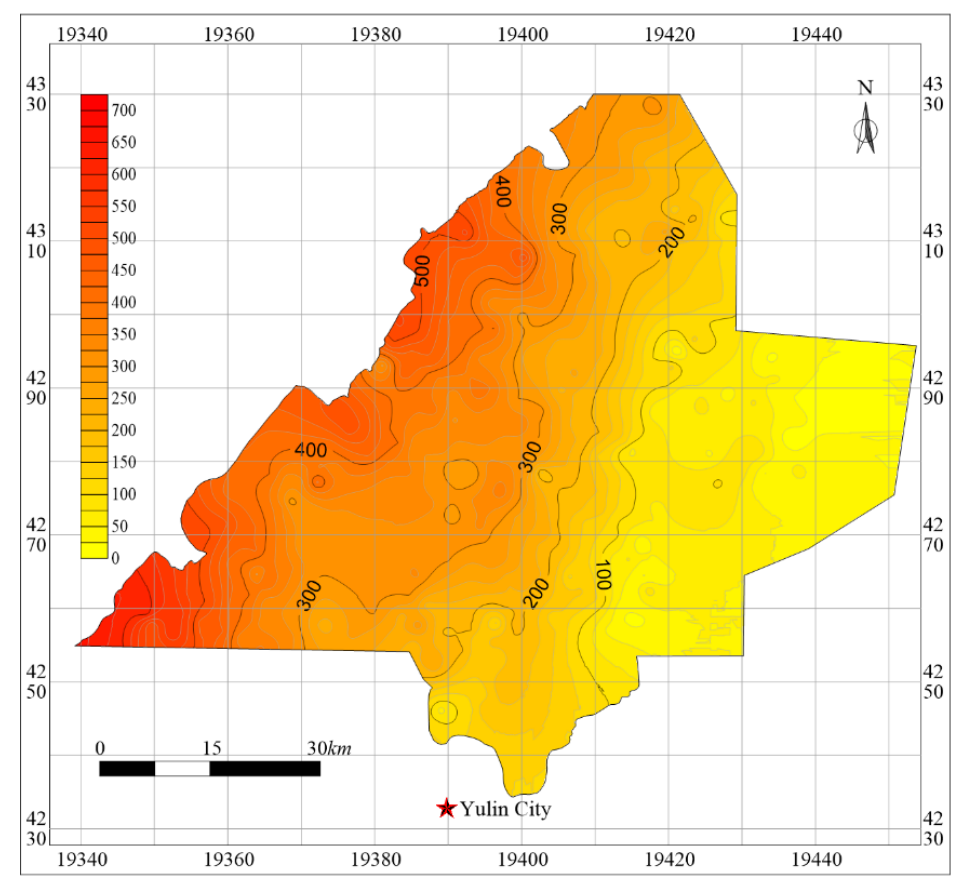

Figure 3. Overburden thickness contour (Xi'an geodetic coordinate system 1980; in km).

The bedrock is weathered and fractured in the first $30 \mathrm{~m}$ depth from surface, and the degree of weathering gradually decreases with the increase of depth. The bedrock from $6 \mathrm{~m}$ to $10 \mathrm{~m}$ depth is highly weathered and secondary structural planes and fracture network was developed. This bedrock layer therefore bears more water than bedrock at high depth. Water yield property of the weathered bedrock varies significantly. It is generally low, except for localized medium levels.

\section{(2) Stratigraphic structure map}

The spatial relationship between coal seams and aquifers (or aquicludes) in the Yu-Shen mining area has the following characteristics: The groundwater is found in close association with the underlying coal, and the bedrock is thick and often covered with a thin layer of sandy soil. The distance between coal seam and aquifer varies significantly. The thickness of bedrock above coal seam is negatively correlated with aquifer thickness. A decrease in bedrock thickness indicates increase in aquifer thickness and water yield. An increase in bedrock thickness is associated with decreases in aquifer thickness and lower water yield. The increase in bedrock thickness occurs mostly near boundaries between zones of different water yields. 
The stratigraphic structure of overburden in the Yu-Shen mining area was categorized into five types: sand-soil-bedrock (I), sand-bedrock (II), bedrock (III), soil-bedrock (IV), and burnt rock (V) as shown in Figure 4. The overburden of sand-soil-bedrock is composed of sand, impermeable soil and bedrock. This stratigraphic structure is widely distributed in this mining area, covering more than $80 \%$ of its territory. The sand-bedrock overburden is very thin. The high-yield unconsolidated aquifer in this structure lies directly above the coal-bearing strata, and there is no continuous clay aquiclude separating them. The bedrock overburden consists of bedrock only which is exposed to the earth's surface. There is no need to consider water conservation here due to the extremely low water bearing capacity. Soil-bedrock overburden is composed of soil and bedrock. As it bears no water, water conservation is not accounted for in this structure. Burnt rock is the product of rock alteration resulting from the spontaneous combustion of coal seams $2^{-2}$ and $3^{-1}$. Burnt rock overburden thickness ranges from $30 \mathrm{~m}$ to $50 \mathrm{~m}$, and its degree of metamorphism gradually decreases as the increase of vertical distance from the spontaneous combustion seams.

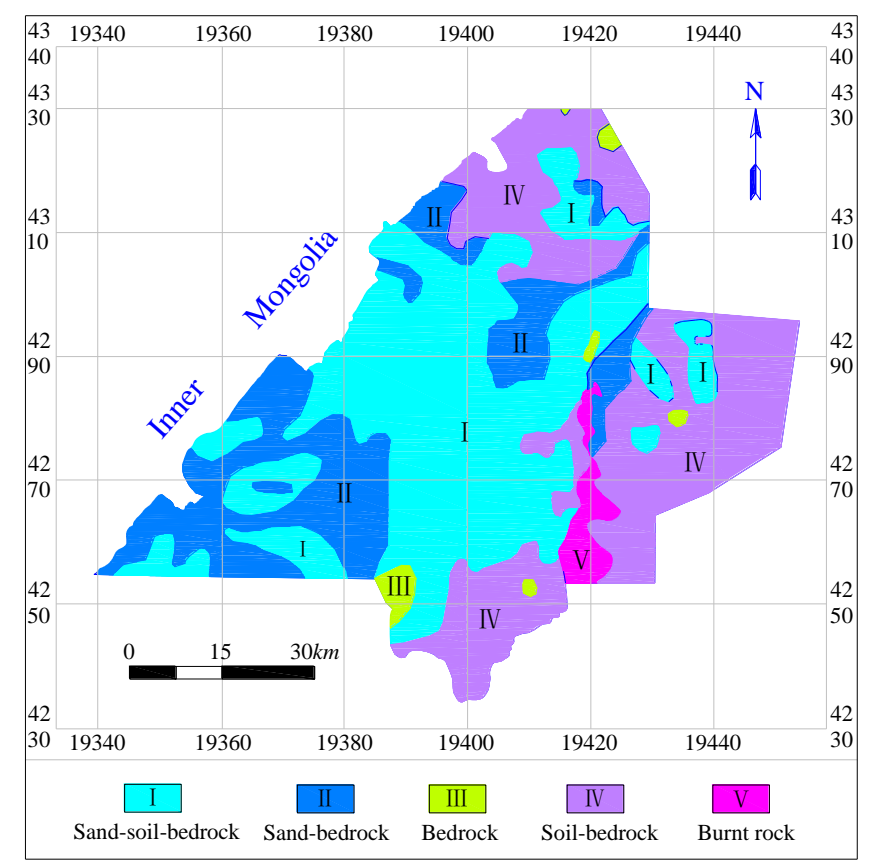

Figure 4. Stratigraphic structure map (Xi'an geodetic coordinate system 1980; in km).

(3) Water-rich zoning map of aquifers

The major types of aquifers in the Yu-Shen mining area, from top to bottom, include: the unconsolidated porous phreatic aquifer, Salawusu Formation aquifer, burnt rock phreatic aquifer, and fractured (porous) bedrock confined aquifer, as shown in Figure 5. The fractured (porous) bedrock confined aquifer has extremely low water content due to limited distribution and relatively high permeability, the burnt rock phreatic aquifer cannot form a water-storing structure. However, it is primarily recharged by groundwater from the water-bearing Salawusu Formation. Therefore, the Salawusu Formation is the major aquifer in this area which needs to be protected during mining.

Holocene $\left(\mathrm{Q}_{4}\right)$ porous phreatic aquifers include Holocene eolian sand layer $\left(\mathrm{Q}_{4}{ }^{\mathrm{eol}}\right)$ and Holocene alluvial deposit $\left(\mathrm{Q}_{4}{ }^{\mathrm{al}}\right)$. Holocene eolian sand layer $\left(\mathrm{Q}_{4}{ }^{\mathrm{eol}}\right)$ is widely distributed in Yu-Shen mining area, with an average thickness of $5 \mathrm{~m}$, and is mainly composed of fine sand and silt, this layer is permeable and bears no water. Holocene alluvial deposit $\left(\mathrm{Q}_{4}{ }^{\text {al }}\right)$ is mainly found in large river valleys and fluvial terraces, with limited distribution and having small thicknesses. This layer basically plays no part in local water supply. These two layers and the underlying Salawusu Formation usually form a complete aquifer. 


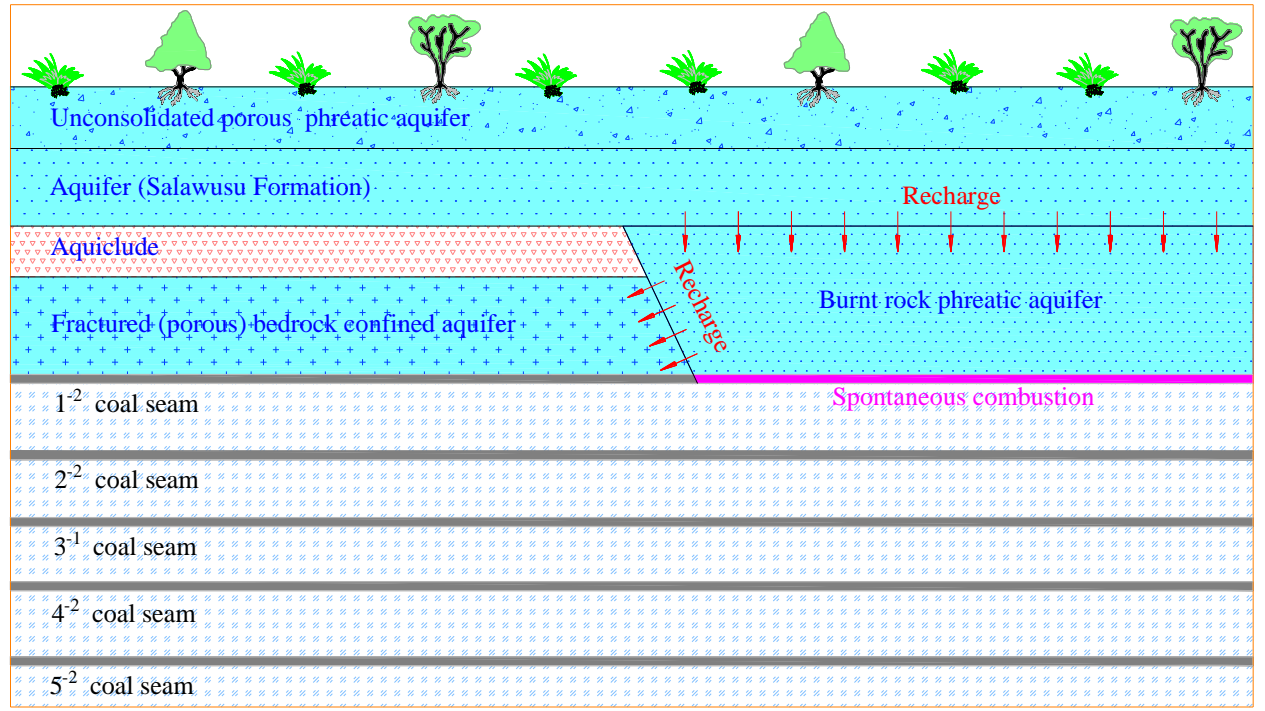

Figure 5. The major types of aquifers in the Yu-Shen mining area.

The water-bearing Salawusu Formation has wide distribution in the mine area. It is normally covered with eolian sand. Its thickness ranges from $0 \mathrm{~m}$ to $67.3 \mathrm{~m}$. The water table is generally less than $10 \mathrm{~m}$ underground (normally $0.9-9.3 \mathrm{~m}$ deep). This formation mainly consists of silt, fine sand, medium sand, and contains sandy loam. With high porosity, the Salawusu Formation is the major aquifer in the study area. Its spatial distribution, thickness, and aquifer structure are strictly governed by modern topographic features and the paleogeographic environment in which it was deposited. The hydrological conditions and water yield of this aquifer vary significantly across this area. The high water-rich part of the aquifer covers a total area of $504 \mathrm{~km}^{2}$ with a thickness of $39.6-156.1 \mathrm{~m}$ and is characterized with permeability coefficient of $0.055-23.6 \mathrm{~m} / \mathrm{d}$. Its medium water-rich portion is about $1911 \mathrm{~km}^{2}$ in total, having depth varies from $6.42-145.50 \mathrm{~m}$ and permeability coefficient varies from $0.005-10.457 \mathrm{~m} / \mathrm{d}$. The low water-rich portion is $1919 \mathrm{~km}^{2}$ in total, with the depth varies between $4.4-93.8 \mathrm{~m}$, and permeability coefficient varies between $0.012-6.073 \mathrm{~m} / \mathrm{d}$. The water-rich zoning map of aquifers is shown in Figure 6.

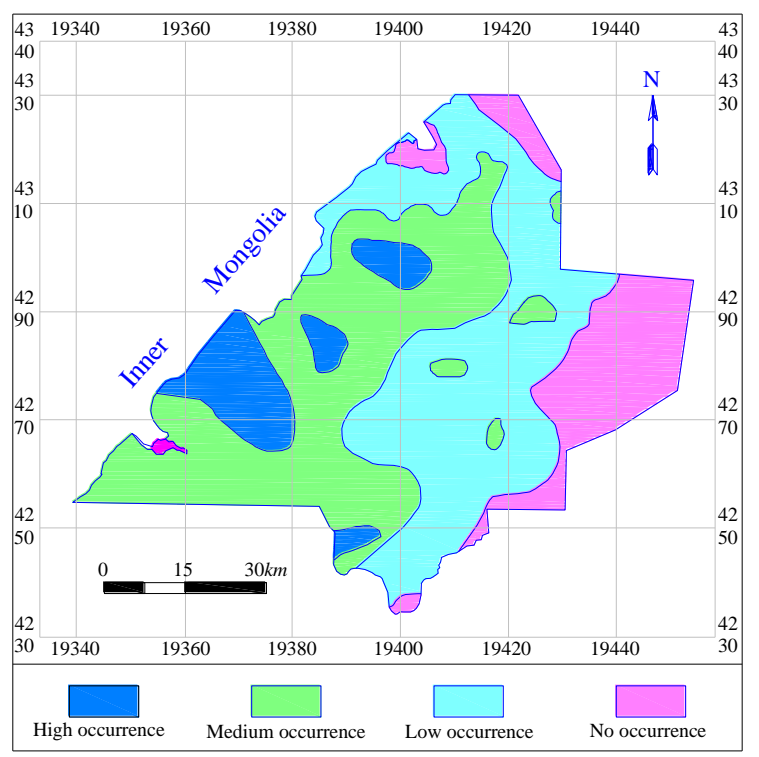

Figure 6. Water-rich zoning map of aquifers (Xi'an geodetic coordinate system 1980; in km). 
(4) Aquiclude thickness contour

The main aquicludes in this mining area include the loess in the Lishi Formation and red soil in the Pliocene Baode Formation, as shown in Figure 7. The Lishi Formation is a loess formation composed of grayish-yellow sandy loam and silty clay, with $45.7 \%$ sand, $39.5 \%$ silt, and $14.8 \%$ clay. Its upper part is eolian loess $\left(\mathrm{Q}_{3} \mathrm{~m}\right)$ with well-developed joints and pores. The Lishi loess is well graded, and its coefficient of non-uniformity is 2.0, and the coefficient of curvature is 1.5. The loess's moisture content varies between $11.9-17.3 \%$, plastic limit between $16.9-18.7 \%$, liquid limit between $25.9-31.8 \%$, and plasticity index between 7.9-13.1. These parameters indicate that the loess is in a hard to hard plastic state. The thickness of the Lishi Formation varies with an average of $23.0 \mathrm{~m}$. It is in discordant contact with the underlying layer.

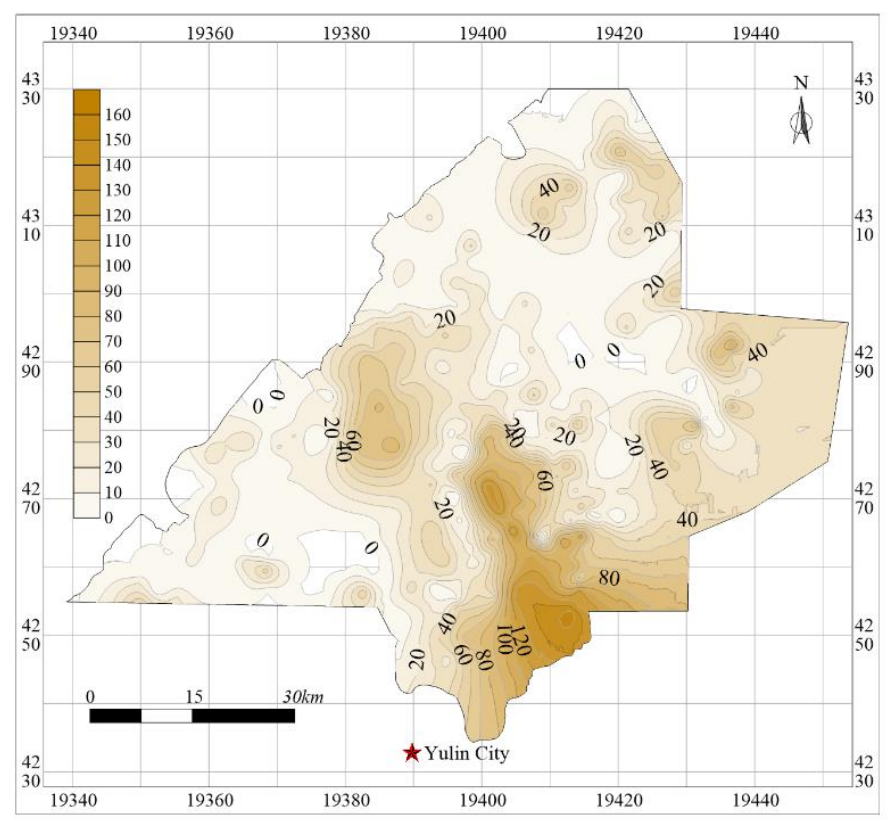

Figure 7. Aquiclude thickness contour map (Xi'an geodetic coordinate system 1980; in km).

The Baode Formation is a red soil formation consisting of brown-red clay and silty clay. The mineralogical composition is chlorite as the dominant mineral of this formation, while kaolinite and illite present in small quantities, having medium plasticity index (from 9.5 to 12.1), medium liquid limit, and low liquidity index, this red soil is a hard plastic clay soil. The thickness of this formation is $30 \mathrm{~m}$ on average, which is controlled by the ancient base levels of erosion in this area. It is relatively thick along the water-shed and then decreases gradually towards the valleys on each side.

(5) Coal thickness contour

The Jurassic Yan'an Formation is the coal-bearing formation in this area. It contains five main coal seams referred to as $1^{-2}, 2^{-2}, 3^{-1}, 4^{-2}$ and $5^{-2}$. These seams are generally flat with small dip angles of $1^{\circ}$ to $3^{\circ}$ but their thicknesses vary significantly. The maximum seam thickness is greater than $12 \mathrm{~m}$, as shown in Figure 8. Seam $1^{-2}$ occurs in the upper part of the 5th section of the Yan'an Formation. Seams $2^{-2}$ and $3^{-1}$ are at the top of the 4 th and 3 rd sections, respectively. Seam $4^{-2}$ is in the mid-upper part of the 2 nd section of this formation and $5^{-2}$ is at the top of the first section. 


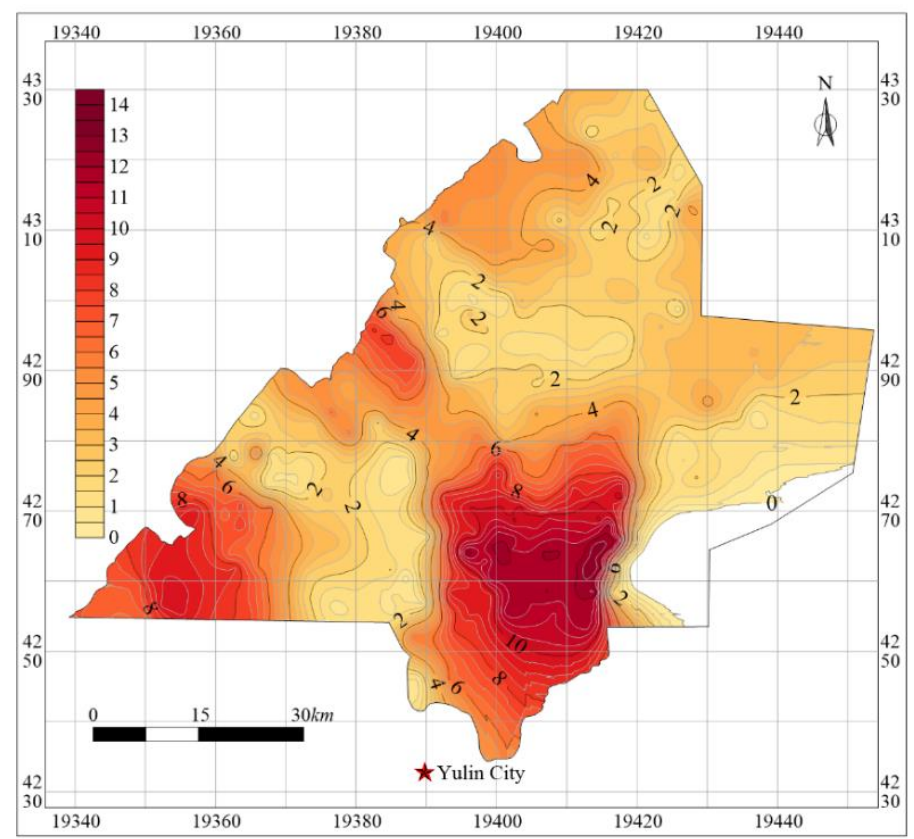

Figure 8. Coal thickness contour (Xi'an geodetic coordinate system 1980; in km).

\section{Determination of the Heights of "Three Zones"}

\subsection{Longwall Mining}

In a longwall mine, several interconnected roadways are developed as passageways (often called gate roads) for operators, equipment, coal transport, and ventilation. These roadways split the coal seam into longwall panels, which are typically 100-300 m wide and 1000-5000 m long. A shearer is mounted along the width of each panel, i.e., the longwall face, and cuts coal in 0.6-1.2 $\mathrm{m}$ thick slices from the seam as it moves along the face. Chain pillars are usually left between panels, and the roadways on the two sides of a pillar are connected by crosscuts as shown in Figure 9.

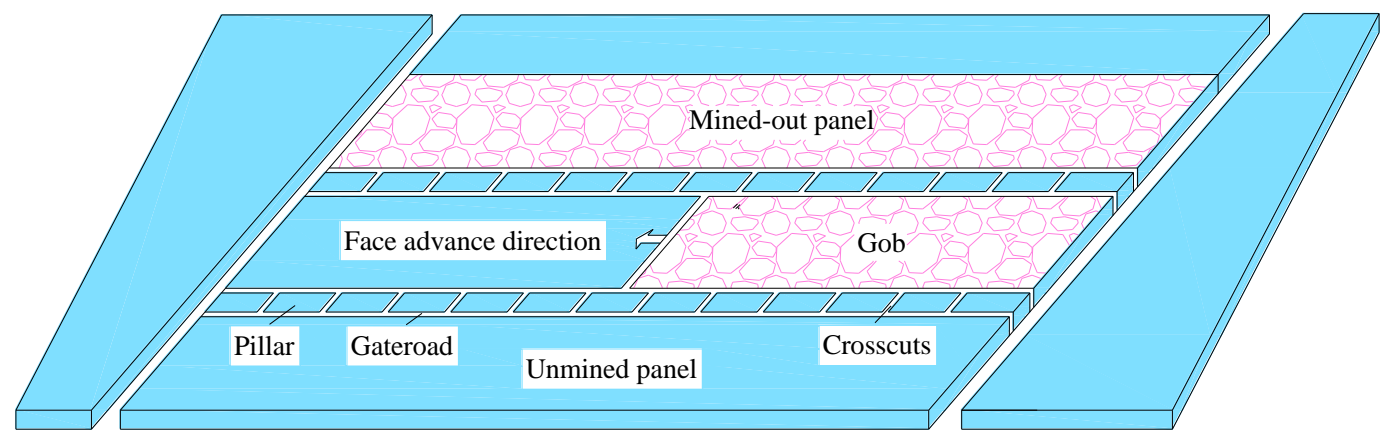

Figure 9. Longwall panel layout.

Longwall mining has been widely used in the United States, Australia, Poland and India because of its significant advantages, e.g., continuous mining, high productivity, high efficiency and high seam recovery rate etc. It is also extensively used by coal mines in Northwest China, where the coal seams are typically thick and shallow [25]. However, high intensity longwall mining leads to severe fracturing in the overlying strata to reach the aquifer, which cause groundwater to infiltrate to longwall working face along the fractures and surface vegetation to die, as shown in Figure 10.

After the coal seam is extracted, the overburden tends to collapse, forming goaf (gob) behind face. Generally, the goaf can be divided into three zones based on the degree of damage: caved zone, 
fractured zone, and continuous deformation zone as shown in Figure $10[39,40]$. The caved zone and fractured zone are known as the WCFZ as they provide the main paths for groundwater flow [41].

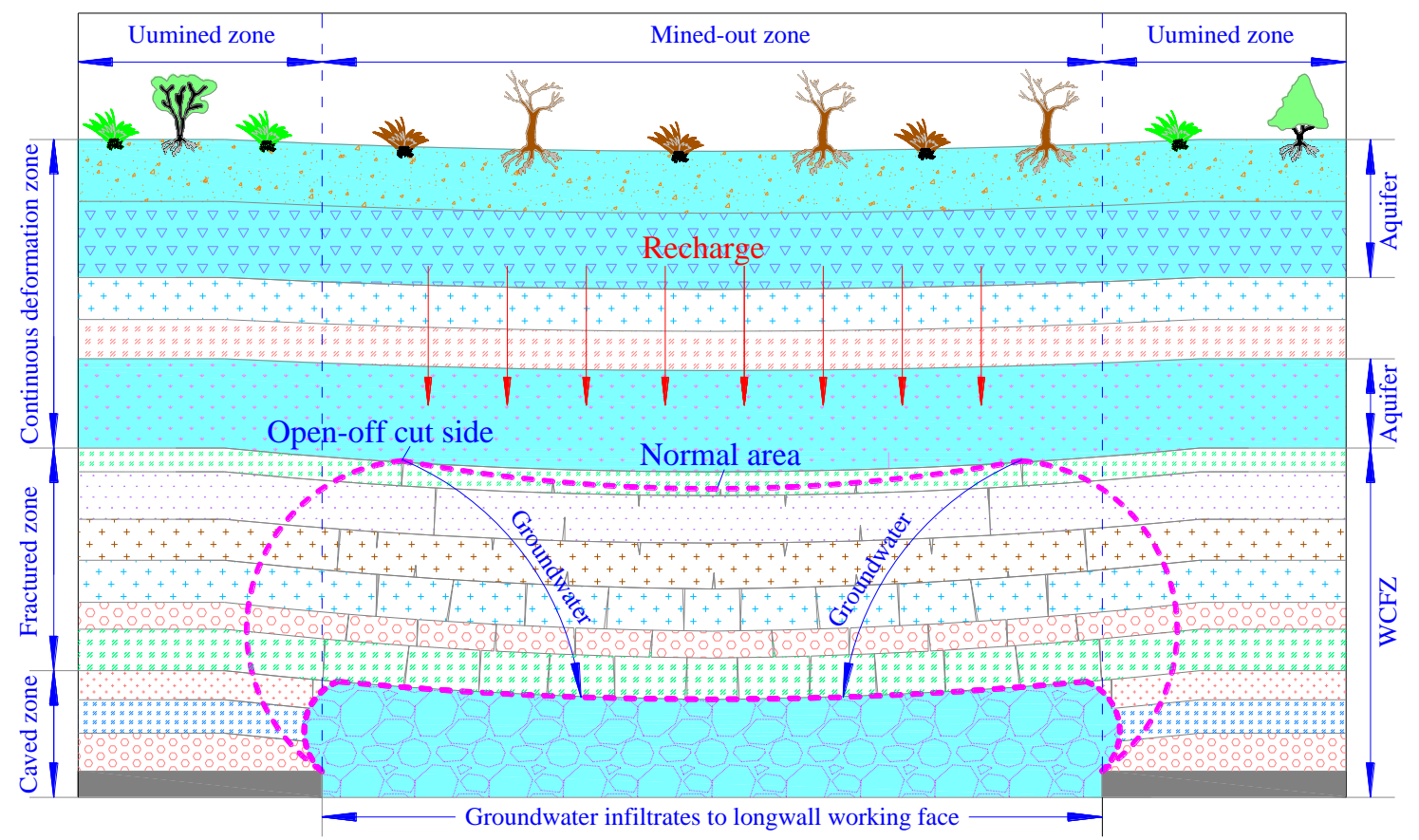

Figure 10. The three zones in overlying strata and groundwater inrush resulting from longwall mining.

\subsection{Height of Caved Zone}

The ratio of caved zone height to mining height in Yu-Shen mining area was measured and found between 4.12 and 6.38 as describe in Table 2. According to the measured data, the equation of calculating the height of caved zone is obtained:

$$
H_{k}=\frac{100 M}{0.6 M+14.1}
$$

where, $H_{k}$ is the height of caved zone $(\mathrm{m})$ and $M$ is the effective mining height $(\mathrm{m})$.

Table 2. Field observation of caved zone height and WCFZ height in Yu-Shen mining area.

\begin{tabular}{|c|c|c|c|c|c|c|}
\hline Coal Mine & $\begin{array}{c}\text { Working } \\
\text { Face/Borehole }\end{array}$ & $\begin{array}{c}\text { Mining } \\
\text { Height (m) }\end{array}$ & $\begin{array}{l}\text { Caved Zone } \\
\text { Height }(\mathrm{m})\end{array}$ & $\begin{array}{l}\text { The Ratio of Caved } \\
\text { Zone Height to } \\
\text { Mining Height }\end{array}$ & $\begin{array}{l}\text { WCFZ } \\
\text { Height } \\
\text { (m) }\end{array}$ & $\begin{array}{l}\text { The Ratio of } \\
\text { WCFZ Height to } \\
\text { Mining Height }\end{array}$ \\
\hline \multirow[t]{2}{*}{ Jinjitan } & 101 & 5.5 & 23.14 & 4.2 & 108.59 & 20.54 \\
\hline & Y3 & 5 & 24.50 & 4.90 & 130.50 & 26.10 \\
\hline \multirow{2}{*}{ Yushuwan } & Y4 & 5 & 27.90 & 5.58 & 137.30 & 27.46 \\
\hline & Y6 & 5 & 20.60 & 4.12 & 117.80 & 23.56 \\
\hline \multirow{4}{*}{ Hanglaiwan } & $\mathrm{H} 3$ & 4.5 & 20.50 & 4.56 & 108.32 & 24.07 \\
\hline & $\mathrm{H} 4$ & 4.5 & 22.18 & 4.93 & 114.38 & 25.42 \\
\hline & H5 & 4.5 & 19.40 & 4.31 & 107.83 & 23.96 \\
\hline & H6 & 4.5 & 28.70 & 6.38 & 93.87 & 20.86 \\
\hline
\end{tabular}

The height of the caved zone near each borehole was calculated using Equation (3). The results obtained is plotted showing the caved zone height in an area as shown in Figure 11. 


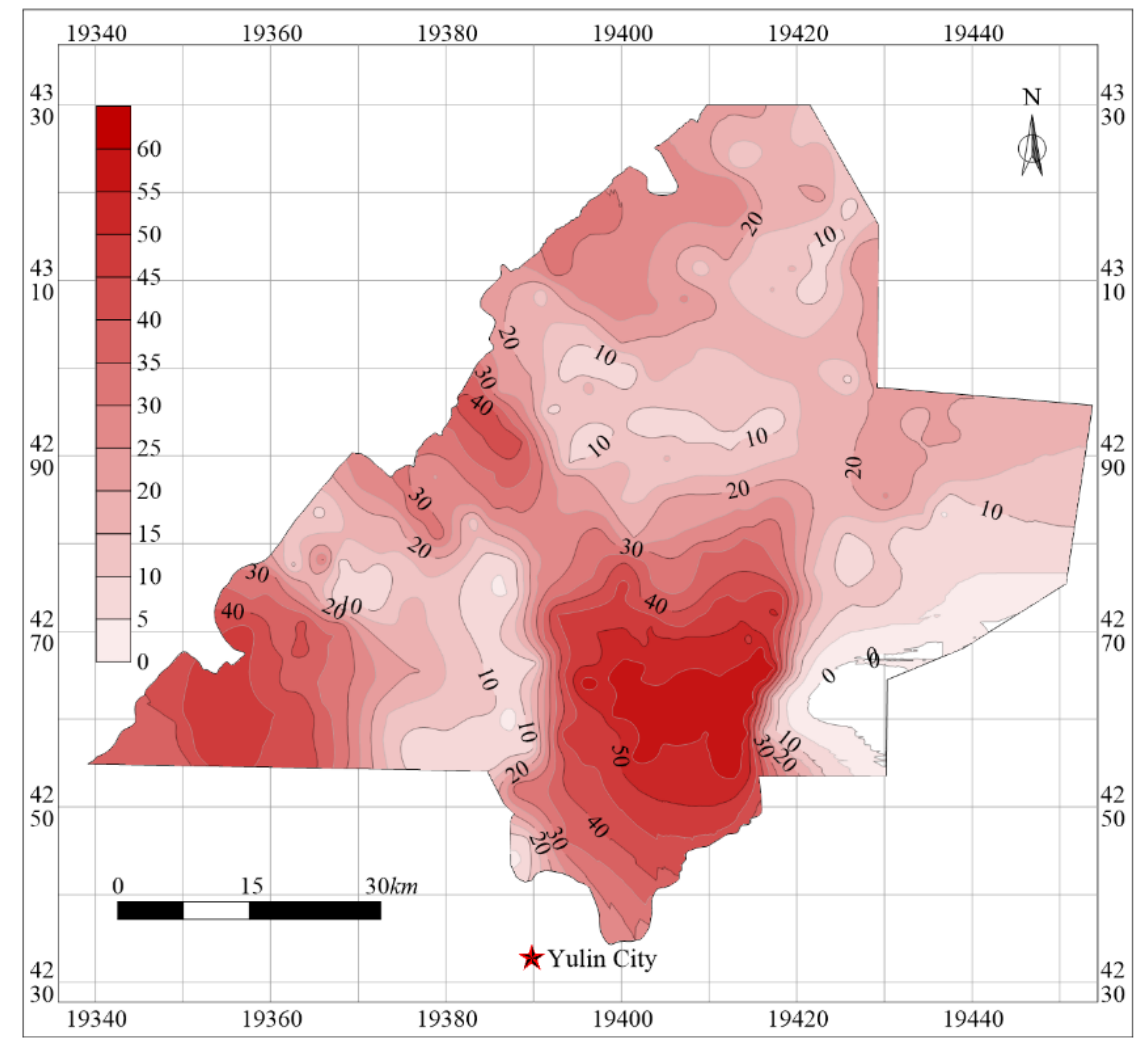

Figure 11. Caved zone height contour ( $\mathrm{Xi}^{\prime}$ an geodetic coordinate system 1980; in km).

\subsection{Height of WCFZ}

To determine the height of WCFZ, four main methods can be used: field measurement, numerical modeling, empirical equation, and physical modeling. As it is difficult to obtain accurate results by each single method, a combination of two or more of them is usually used.

\section{(1) Field measurements}

The location of top boundary and height of WCFZ induced by mining of each main seam in Yu-Shen mining area were determined through observation of: drilling fluid loss combined with engineering geological logging of rock cores, packer testing, borehole television logging, and geophysical logging [42,43]. The measured heights of WCFZ detail are given in Table 2.

The average measured ratio of WCFZ height to mining height in the study area was 24.73. Overall, the ratio decreases with the increase of mining height.

\section{(2) Numerical calculation}

The thickness of the main coal seam in the Yu-Shen mining area varies between 0.3-12.4 $\mathrm{m}$, while the mining height obtained according to the measured height of WCFZ varies from 3.5 to $5.5 \mathrm{~m}$. In order to thoroughly analyze the height of WCFZ under different stratigraphic structures and mining heights, the universal distinct element code (UDEC) was employed and four numerical calculation models were developed. In these numerical models, the height of WCFZ under different mining heights was calculated for stratigraphic structures of sand-soil-bedrock, sand-bedrock, bedrock and soil-bedrock respectively. It is noted that, for the stratigraphic structure of burnt rock, the burial depth of coal seam is less than $150 \mathrm{~m}$, and the mining-induced WCFZ will generally develop and reach the surface. Therefore, it is not necessary to simulate the height of the WCFZ of the burnt rock.

Based on the stratigraphic column of the Yu-Shen mining area, numerical calculation models were developed to simulate the height of WCFZ based on different boreholes. The model parameters were continuously optimized until a good agreement of the numerical results and the field measured results 
was reached. Taking the typical sand-soil-bedrock stratigraphic structure as example, similar lithologic strata were merged and 14 strata were identified from bottom to top according to the Y5 borehole in Yushuwan Coal Mine. The numerical model with dimensions of $800 \mathrm{~m} \times 302 \mathrm{~m}$ was constructed based on reducing the boundary effect and supercritical mining as shown in Figure 12. The left and right sides of the model were fixed in the $\mathrm{X}$ direction, and the bottom boundary of the model was fixed in the Y direction. Mohr-Coulomb model was used during the calculation. The WCFZ height for $5 \mathrm{~m}$ mining height is calculated and continuously adjusting parameters according to the numerical results, the optimum model parameters which can result in the measured results were obtained, and they are shown in Tables 3 and 4.

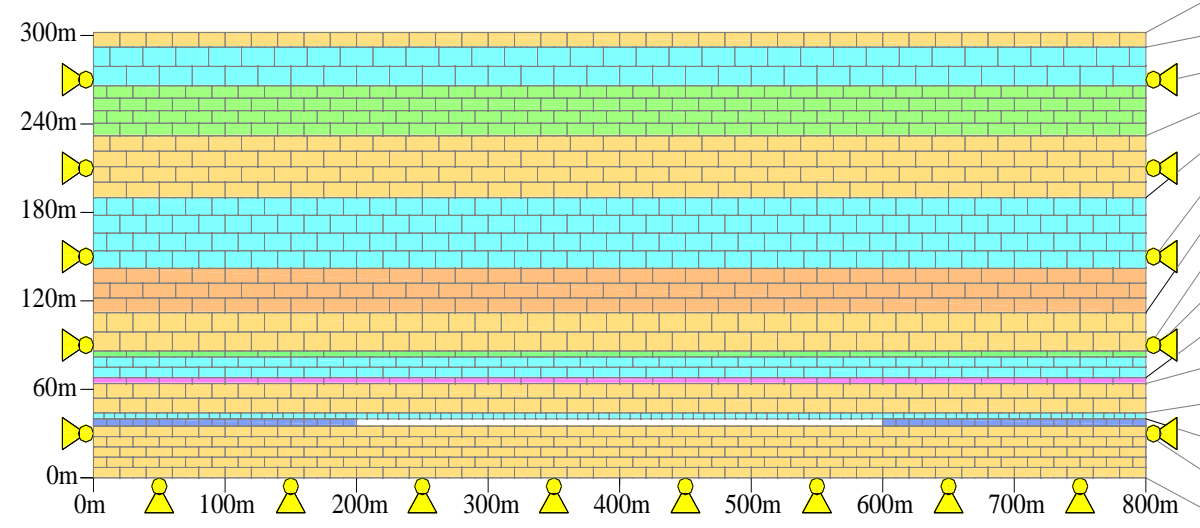

\begin{tabular}{|c|c|}
\hline Lithology & $\begin{array}{c}\text { Thickness } \\
(\mathrm{m})\end{array}$ \\
\hline Fine sandstone & 10.0 \\
\hline Siltstone & 26.0 \\
\hline Clay & 34.0 \\
\hline Fine sandstone & 42.0 \\
\hline Siltstone & 48.0 \\
\hline Coarse sandstone & 30.0 \\
\hline Fine sandstone & 26.0 \\
\hline Mudstone & 4.0 \\
\hline Siltstone & 14.0 \\
\hline Medium sanstone & 4.0 \\
\hline Fine sandstone & 20.0 \\
\hline Siltstone & 4.0 \\
\hline Coal seam & 5.0 \\
\hline Fine sandstone & 35.0 \\
\hline
\end{tabular}

Figure 12. Numerical simulation model of sand-soil-bedrock stratigraphic structure.

Table 3. Rock physical and mechanical parameters (block).

\begin{tabular}{|c|c|c|c|c|c|c|c|c|}
\hline Number & Strata & $\begin{array}{l}\text { Thickness } \\
\text { (m) }\end{array}$ & $\begin{array}{l}\text { Density } \\
\left(\mathrm{kg} / \mathrm{m}^{3}\right)\end{array}$ & $\begin{array}{c}\text { Bulk } \\
\text { Modulus } \\
\text { (GPa) }\end{array}$ & $\begin{array}{l}\text { Shear } \\
\text { Modulus } \\
\text { (GPa) }\end{array}$ & $\begin{array}{l}\text { Cohesion } \\
\text { (MPa) }\end{array}$ & $\begin{array}{c}\text { Friction } \\
\text { Angle }\left(^{\circ}\right)\end{array}$ & $\begin{array}{c}\text { Tensile } \\
\text { Strength } \\
\text { (MPa) }\end{array}$ \\
\hline 1 & $\begin{array}{c}\text { Fine } \\
\text { sandstone }\end{array}$ & 10 & 2600 & 30.8 & 20.3 & 5.6 & 35 & 4.0 \\
\hline 2 & Siltstone & 26 & 2460 & 16.1 & 11.6 & 2.0 & 21 & 1.2 \\
\hline 3 & Clay & 34 & 1900 & 0.28 & 0.093 & 0.85 & 25 & 0.35 \\
\hline 4 & $\begin{array}{c}\text { Coarse } \\
\text { sandstone }\end{array}$ & 30 & 2500 & 20.8 & 11.9 & 3.0 & 23 & 1.4 \\
\hline 5 & Mudstone & 4 & 2200 & 8.3 & 4.3 & 2.1 & 25 & 1.0 \\
\hline 6 & $\begin{array}{l}\text { Medium } \\
\text { sandstone }\end{array}$ & 4 & 2560 & 23.1 & 14.5 & 4.4 & 2.8 & 2.0 \\
\hline 7 & Coal seam & 10 & 1400 & 2.0 & 1.4 & 1.7 & 28 & 1.5 \\
\hline
\end{tabular}

Table 4. Rock physical and mechanical parameters (contact).

\begin{tabular}{|c|c|c|c|c|c|c|}
\hline Number & Strata & $\begin{array}{c}\text { Normal } \\
\text { Stiffness } \\
\text { (GPa) }\end{array}$ & $\begin{array}{c}\text { Shear } \\
\text { Stiffness } \\
\text { (GPa) }\end{array}$ & $\begin{array}{l}\text { Cohesion } \\
\text { (MPa) }\end{array}$ & $\begin{array}{c}\text { Friction } \\
\text { Angle }\left({ }^{\circ}\right)\end{array}$ & $\begin{array}{c}\text { Tensile } \\
\text { Strength } \\
\text { (MPa) }\end{array}$ \\
\hline 1 & Fine sandstone & 300 & 200 & 6.5 & 12 & 3.5 \\
\hline 2 & Siltstone & 200 & 160 & 8.0 & 10 & 5.5 \\
\hline 3 & Clay & 300 & 180 & 6.0 & 20 & 3.0 \\
\hline 4 & $\begin{array}{c}\text { Coarse } \\
\text { sandstone }\end{array}$ & 500 & 400 & 4.0 & 25 & 3.0 \\
\hline 5 & Mudstone & 300 & 100 & 2.1 & 20 & 1.5 \\
\hline 6 & $\begin{array}{l}\text { Medium } \\
\text { sandstone }\end{array}$ & 150 & 100 & 4.2 & 15 & 2.2 \\
\hline 7 & Coal seam & 500 & 350 & 9.0 & 15 & 6.0 \\
\hline
\end{tabular}


The WCFZ of $5 \mathrm{~m}$ mining height is shown in Figure 13. The optimized model parameters were used, the heights of WCFZ zone under different mining heights were calculated for 4 different stratigraphic structures, and the results are shown in Table 5.

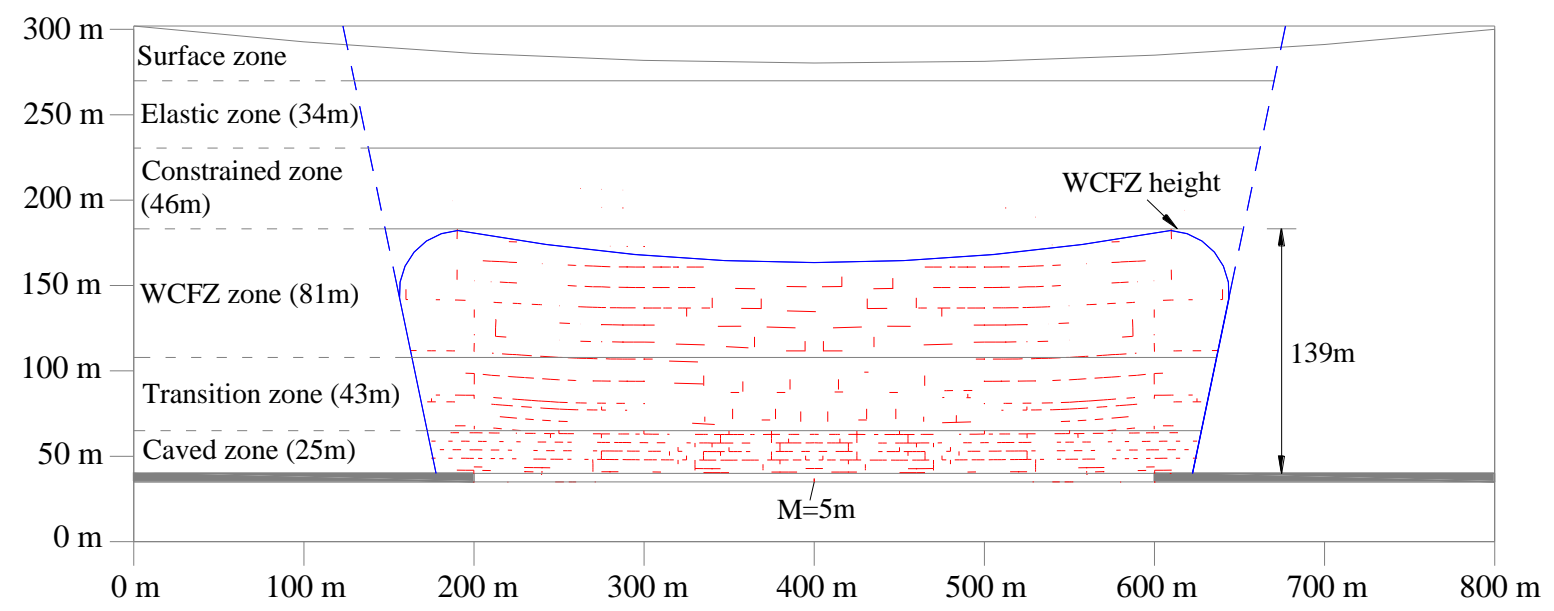

Figure 13. WCFZ of $5 \mathrm{~m}$ mining height of sand-soil-bedrock stratigraphic structure.

Table 5. Numerical simulation results of WCFZ height and the ratio of WCFZ height to mining height.

\begin{tabular}{|c|c|c|c|c|c|c|c|c|}
\hline \multirow[b]{2}{*}{$\begin{array}{l}\text { Mining } \\
\text { Height } \\
\text { (m) }\end{array}$} & \multicolumn{2}{|c|}{ Sand-Soil-Bedrock } & \multicolumn{2}{|c|}{ Sand-Bedrock } & \multicolumn{2}{|c|}{ Bedrock } & \multicolumn{2}{|c|}{ Soil-Bedrock } \\
\hline & $\begin{array}{c}\text { WCFZ } \\
\text { Height } \\
\text { (m) }\end{array}$ & $\begin{array}{c}\text { The Ratio of } \\
\text { WCFZ Height } \\
\text { to Mining } \\
\text { Height }\end{array}$ & $\begin{array}{c}\text { WCFZ } \\
\text { Height } \\
\text { (m) }\end{array}$ & $\begin{array}{l}\text { The Ratio of } \\
\text { WCFZ Height } \\
\text { to Mining } \\
\text { Height }\end{array}$ & $\begin{array}{c}\text { WCFZ } \\
\text { Height } \\
\text { (m) }\end{array}$ & $\begin{array}{c}\text { The Ratio of } \\
\text { WCFZ Heightto } \\
\text { Mining Height }\end{array}$ & $\begin{array}{l}\text { WCFZ } \\
\text { Height } \\
\text { (m) }\end{array}$ & $\begin{array}{c}\text { The Ratio of } \\
\text { WCFZ Height } \\
\text { to Mining } \\
\text { Height }\end{array}$ \\
\hline 2 & 64 & 32.0 & 68 & 34.0 & 53 & 26.5 & 67 & 33.5 \\
\hline 3 & 92 & 30.7 & 101 & 33.7 & 78 & 26.0 & 91 & 30.3 \\
\hline 4 & 119 & 29.8 & 131 & 32.8 & 101 & 25.3 & 113 & 28.3 \\
\hline 5 & 139 & 27.8 & 154 & 30.8 & 122 & 24.4 & 141 & 28.2 \\
\hline 6 & 165 & 27.5 & 179 & 29.8 & 138 & 23.0 & 169 & 28.2 \\
\hline 7 & 184 & 26.3 & 200 & 28.6 & 153 & 21.9 & 190 & 27.1 \\
\hline 8 & 208 & 26.0 & 221 & 27.6 & 170 & 21.3 & 211 & 26.4 \\
\hline 9 & 218 & 24.2 & 235 & 26.1 & 177 & 19.7 & 226 & 25.1 \\
\hline 10 & 240 & 24.0 & 244 & 24.4 & 187 & 18.7 & 234 & 23.4 \\
\hline
\end{tabular}

\section{(3) Calculation equation}

The equation for WCFZ height calculation was obtained by regression analysis using field measured data under medium thickness seam mining condition in eastern China [31,32]. However, due to the change of coal occurrence, geological and mining conditions, the conventional equation is not suitable for use in the Yu-Shen mining area [44]. Therefore, it is necessary to derive an equation which suits the regional geology based on the measured heights of WCFZ combined with the numerical results [30,33,45-47].

Based on field observations and the numerical simulation results shown in Tables 2 and 5 respectively, four equations for predicting the height of WCFZ were obtained by regression analysis using different stratigraphic structures in Yu-Shen mining area:

$$
\left\{\begin{array}{lll}
H_{d}=21.75 M+28.28 & \mathrm{R}^{2}=0.99 & \text { (Sand - soil - bedrock) } \\
H_{d}=22.2 M+37.13 & \mathrm{R}^{2}=0.97 & \text { (Sand - bedrock) } \\
H_{d}=16.7 M+30.8 & \mathrm{R}^{2}=0.97 & \text { (Bedrock) } \\
H_{d}=21.97 M+28.42 & \mathrm{R}^{2}=0.98 & \text { (Soil - bedrock) }
\end{array}\right.
$$

where, $H_{d}$ is the height of WCFZ; $M$ is the mining height.

Using Equation (4), the heights of WCFZ at different borehole positions were calculated. The WCFZ height is shown in Figure 14. 


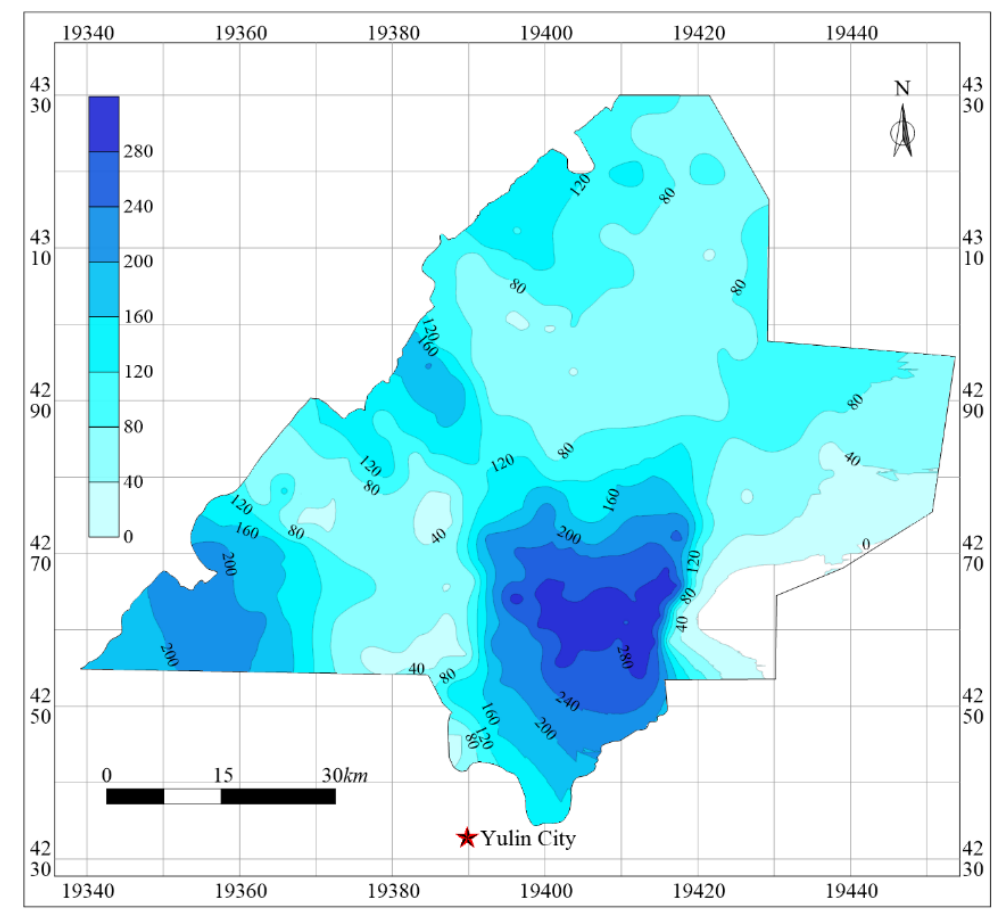

Figure 14. WCFZ height contour (Xi'an geodetic coordinate system 1980; in km).

\subsection{Thickness of Protective Zone}

A protective zone overlying the WCFZ can help to prevent water in the overlying aquifer from flowing into coal faces [31,32]. A water-resisting index based on rock strength was proposed for the quantitative assessment of the water-resisting property of this zone [48]. The more impermeable the protective zone, the higher the index and the harder the rock in the protective zone, the lower the index. If there is a continuous clay layer greater than $3 \mathrm{~m}$ thick separating the WCFZ from the overlying aquifer, it can effectively prevent the downward percolation of water from the aquifer. The amount of water loss, even if only relatively small can cause considerable ecological damage, so the acceptable the safety factor was set at 4 . This means that for a clay layer to be an effective protective zone, its thickness should be at least $12 \mathrm{~m}$. If water-resisting index of clay is 1 , the water-resisting index of the bedrock in the Yu-Shen mining area would be 0.4 for bedrock of sandstone, mudstone and sandy mudstone. Therefore, with the absence of clay, the thickness of bedrock should be at least $30 \mathrm{~m}$ to be an effective protective zone. The method for determining the thickness of protective zone can be expressed as follows:

$$
H_{b}= \begin{cases}12 & \left(H_{t} \geq 12\right) \\ 30-1.5 H_{t} & \left(0 \leq H_{t}<12\right)\end{cases}
$$

where, $H_{b}$ is the thickness of protective zone $(\mathrm{m})$ and $H_{t}$ is thickness of clay layer $(\mathrm{m})$.

Using Equation (5), the thicknesses of protective zone at different boreholes in the Yu-Shen mining area were determined, and the results can be observed in the contour as shown in Figure 15. 


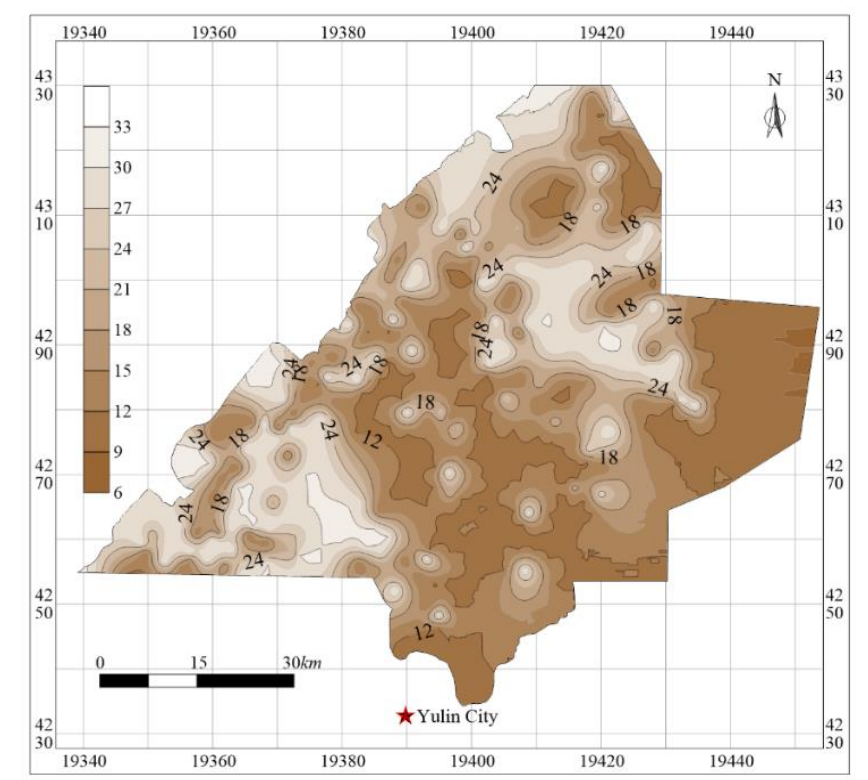

Figure 15. Protection zone thickness contour (Xi'an geodetic coordinate system 1980; in km).

\section{Zoning Based on Coal Mining's Impact Level on Groundwater}

There are five main seams in the Yu-Shen mining area and their thicknesses vary widely. The overall overburden thickness increases gradually from east to west, but regional increase or decrease occurs as a result of change in sedimentary environment or denudation. As the roof strata are relatively unstable, mining activities can easily induce the development of "three zones" (caved zone, WCFZ and protective zone) in the vertical direction. These factors determine that the loss of aquifer water during mining varies spatially and different WCCM method should be implemented according to local conditions. Based on measured bedrock thickness, the spatial relationship between caved zone and WCFZ induced by mining, and the thickness of protective zone, coal mining's impact level on groundwater was classified using the standard summarized in Table 6. Then the study area was divided into zones of different impact levels according to the results, as illustrated in Figure 16:

(1) Unconfirmed zone: the geological data are unavailable in this zone.

(2) No impact zone: the Salawusu Formation is thin or absent, thus there is no effective aquifer.

(3) Slightly impacted zone: the thickness of bedrock over the first mined seam + soil thickness $>$ the height of WCFZ + protective zone thickness. After mining, the WCFZ and aquifer are separated by continuous strata that are thick and impermeable enough to prevent percolation. The aquifer will be effectively protected from mining-induced water loss.

(4) Moderately impacted zone: the height of WCFZ < the thickness of bedrock over the first mined seam + soil thickness $<$ the height of WCFZ + protective zone thickness. There are continuous strata with certain thickness between the WCFZ and the aquifer, but the strata are unable to completely prevent the downward percolation of water from the aquifer.

(5) 'Severely impacted zone: the height of caved zone + protective zone thickness $<$ the thickness of bedrock over the first mined seam + soil thickness $<$ the height of WCFZ. Mining-induced fractures will extend to the aquifer resulting in groundwater loss from the aquifer. The protective zone could only prevent sand inrush.

(6) 'Extremely impacted zone: the thickness of bedrock over the first mined seam + soil thickness $<$ height of caved zone + protective zone thickness. Coal extraction may cause inrush of water and sand. 
Table 6. Classification standard for coal mining's impact level on groundwater.

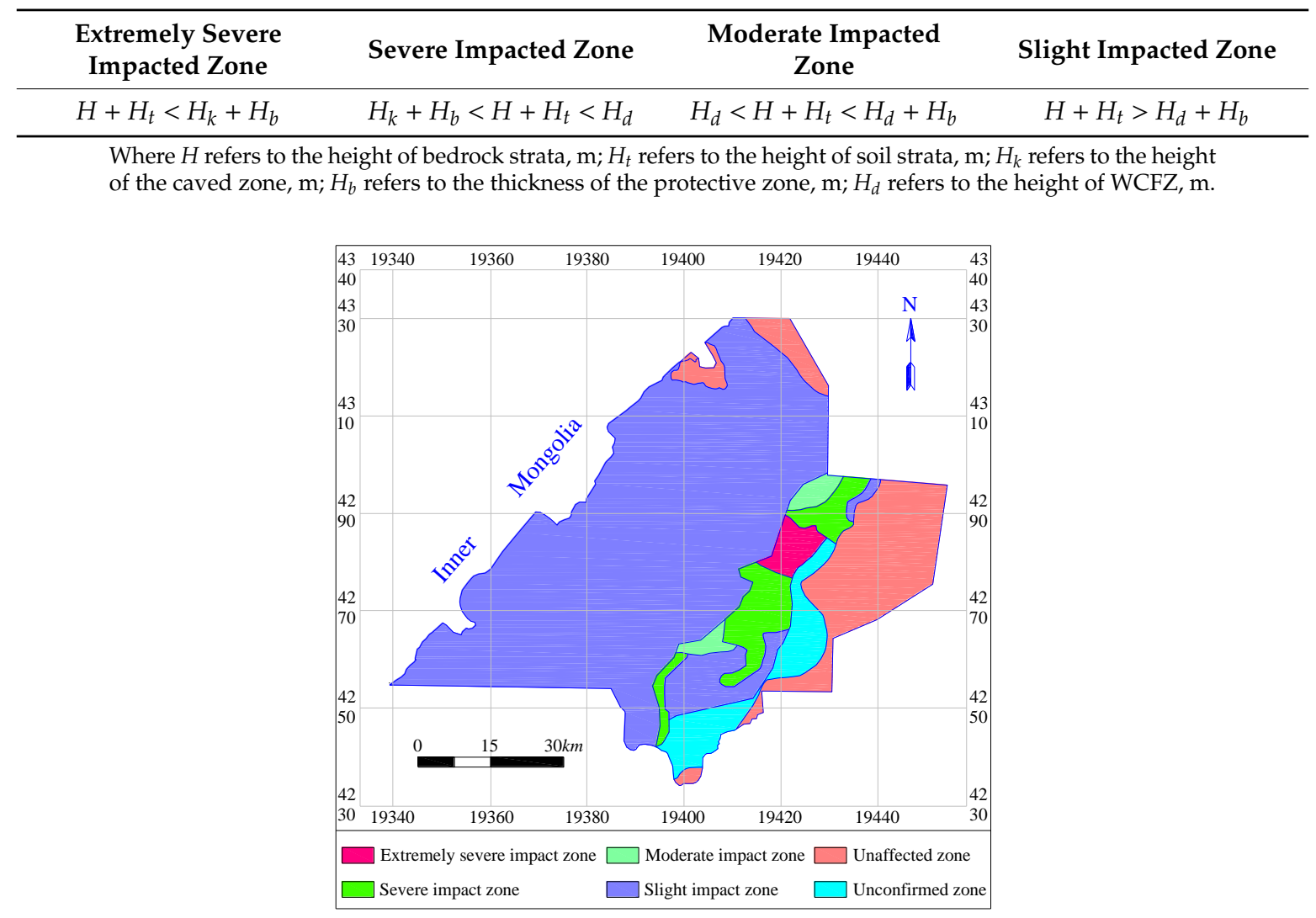

Figure 16. Zoning the extent of coal mining impact on groundwater. (Xi'an geodetic coordinate system 1980; in km).

\section{Zoning Based on Applicability of WCCM Methods}

A system of WCCM methods mainly including restricted mining height, (partial) backfill, and/or narrow strip mining has been established after years of research and practice [49]. Prior to carrying out field practice under site specific geological conditions, the applicability of these methods needs to be considered. The Yu-Shen mining area was then partitioned into zones that are suitable for different WCCM methods.

\subsection{Maximum (Theoretical) Allowable Mining Height}

According to the classification standard for coal mining's impact level on groundwater. If the thickness of soil strata plus the thickness of bedrock is greater than the height of WCFZ plus the height of protective zone, then the WCCM can be realized. Subtracting the necessary thickness of protective zone from the total thickness of soil and bedrock yields the height of WCFZ. The theoretical allowable mining height at each longwall face, $M_{c}$, can be calculated according to Equation (4). The theoretical allowable mining height obtained was then compared with the actual coal thickness, $M_{m}$. Furthermore, the maximum allowable mining height (MAMH), namely the maximum mining height allowed by WCCM, can be derived using Equation (4) under the four different stratigraphic structures:

(1) The equation of MAMH for sand-soil-bedrock overburden is as follows:

$$
M_{c}= \begin{cases}\frac{\left(H+H_{t}-12\right)-28.28}{21.75} & \left(H_{t} \geq 12\right) \\ \frac{\left[H+H_{t}-\left(30-1.5 H_{t}\right)\right]-28.28}{21.75} & \left(0 \leq H_{t}<12\right)\end{cases}
$$


(2) The equation of MAMH for sand-bedrock overburden is as follows:

$$
M_{c}= \begin{cases}\frac{\left(H+H_{t}-12\right)-37.13}{22.2} & \left(H_{t} \geq 12\right) \\ \frac{\left[H+H_{t}-\left(30-1.5 H_{t}\right)\right]-37.13}{22.2} & \left(0 \leq H_{t}<12\right)\end{cases}
$$

(3) The equation of MAMH for bedrock overburden is as follows:

$$
M_{c}= \begin{cases}\frac{\left(H+H_{t}-12\right)-30.8}{16.7} & \left(H_{t} \geq 12\right) \\ \frac{\left[H+H_{t}-\left(30-1.5 H_{t}\right)\right]-30.8}{16.7} & \left(0 \leq H_{t}<12\right)\end{cases}
$$

(4) The equation of MAMH for soil-bedrock overburden is as follows:

$$
M_{c}= \begin{cases}\frac{\left(H+H_{t}-12\right)-28.42}{21.97} & \left(H_{t} \geq 12\right) \\ \frac{\left[H+H_{t}-\left(30-1.5 H_{t}\right)\right]-28.42}{21.97} & \left(0 \leq H_{t}<12\right)\end{cases}
$$

where, $M_{c}$ is the maximum allowable mining height $(\mathrm{m}) ; H$ is bedrock thickness $(\mathrm{m}) ; H_{t}$ is soil thickness (m).

The MAMH contour calculated from Equations (6) to (9), indicating its distribution across Yu-Shen mining area is shown Figure 17.

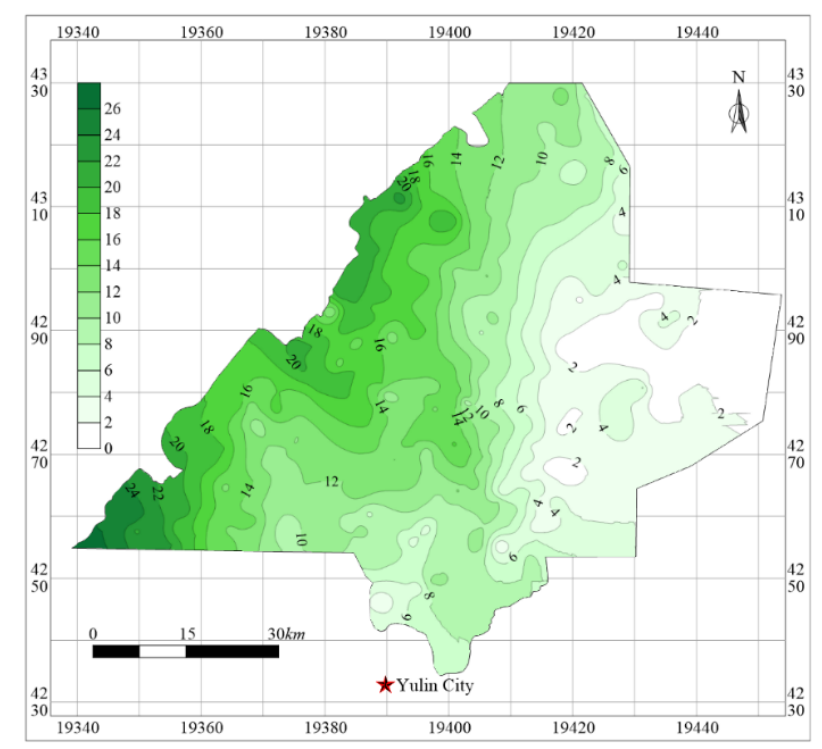

Figure 17. Maximum (theoretical) allowable mining height contour. (Xi'an geodetic coordinate system 1980; in km).

\subsection{Height-Restricted Mining}

In height-restricted mining areas, the mining height is limited for the purpose of reducing overburden displacement and thereby the height of WCFZ. This method can be easily implemented in thick coal seams without extra cost. In addition, the roof over the goaf will collapse completely, thus avoiding the problem of coal pillar failure as occurred in other methods. However, as the coal seam is partially extracted, the recovery rate is obviously lower when using this method.

In height-restricted mining, WCCM is achieved by reducing the actual mining height. Theoretically, it is applicable throughout the study area. Considering the mine production, profit, mining equipment layout and other relevant factors, this method should be more suitable for zones where the maximum allowable mining height $\left(M_{\mathcal{C}}\right)$ is equal or greater than $2 \mathrm{~m}$. The distribution of zones to which height-restricted mining is applicable is shown in Figure 18a. 


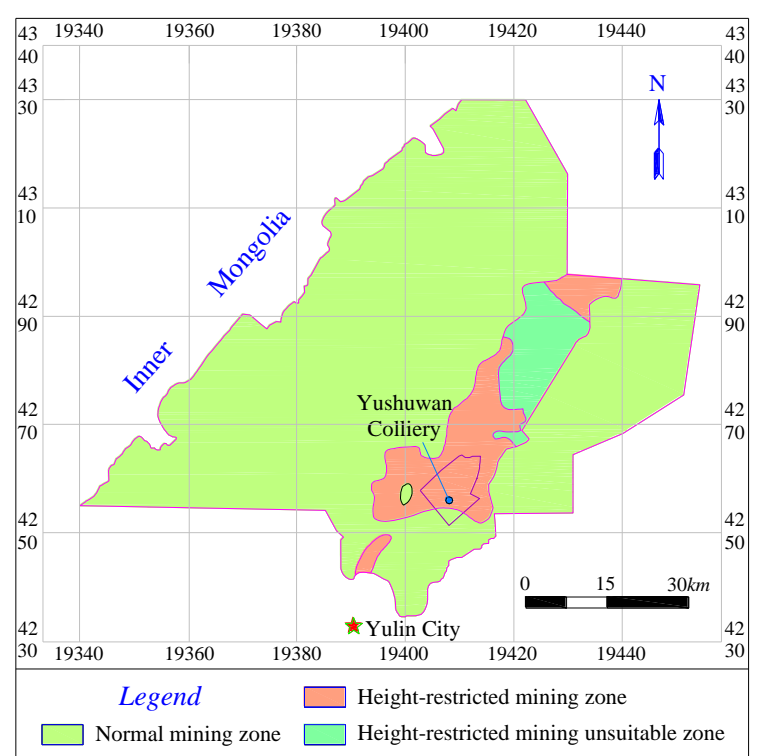

(a)

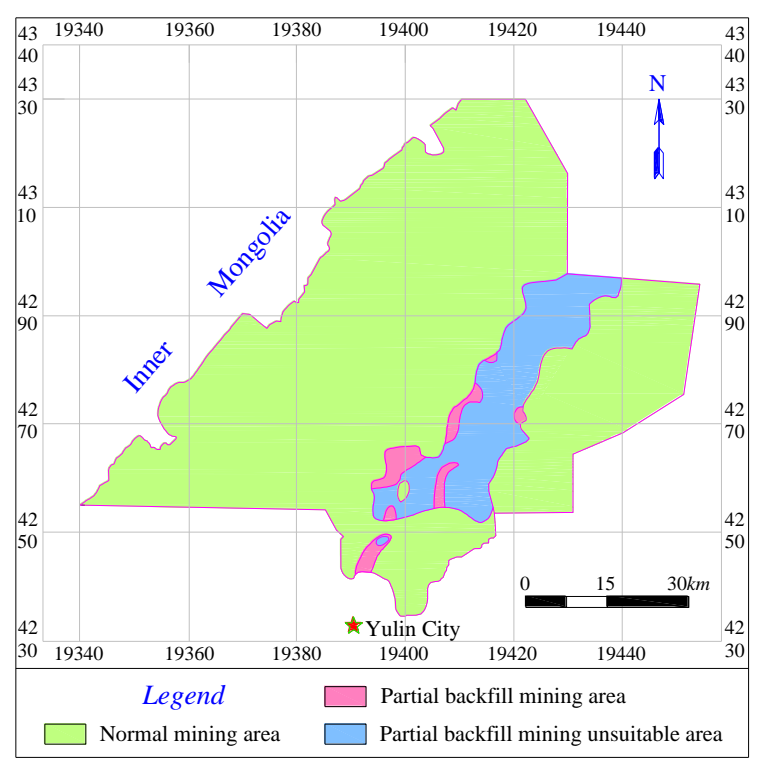

(c)

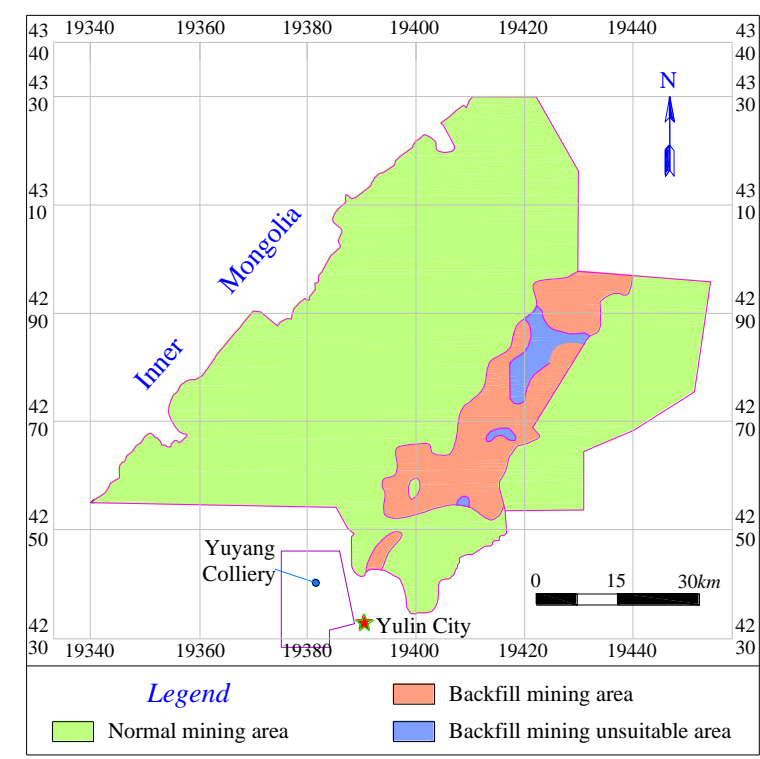

(b)

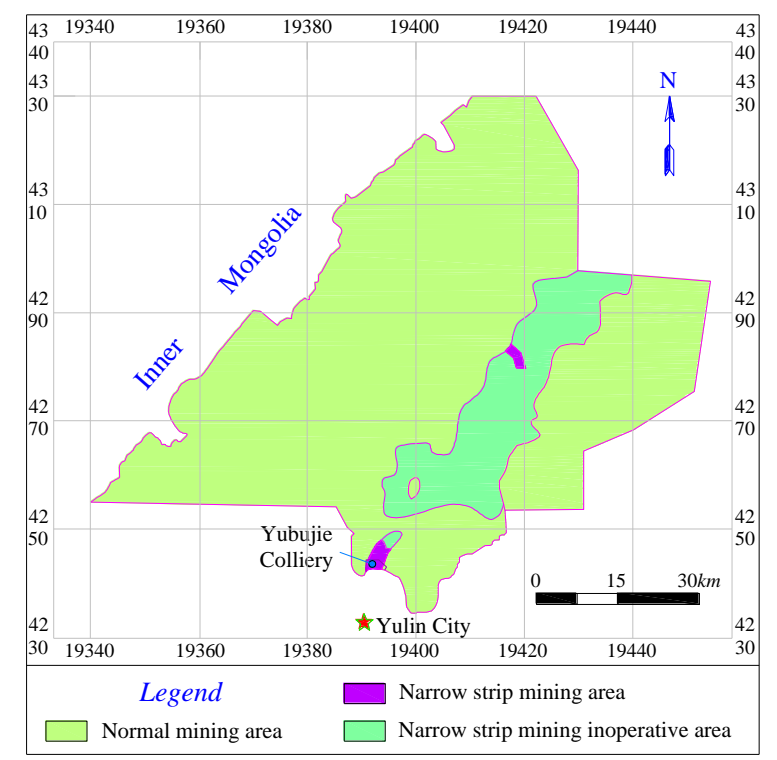

(d)

Figure 18. Applicability partition of water conservation coal mining method ( $\mathrm{Xi}$ 'an geodetic coordinate system 1980; in km): (a) Height-restricted mining application area; (b) Backfill mining application area; (c) Partial backfill mining application area; (d) Narrow strip mining application area.

\subsection{Backfill Mining}

In backfill mining, goaf is refilled with backfill concurrently with mining to support the roof, so to control the overburden movement and deformation, the height of WCFZ is therefore reduced. In this way, aquifers are protected from being disturbed by mining activities and to achieve water conservation. In theory, this method allows all coal resources in an area to be extracted. It is recognized as an ideal approach to protecting water resources from coal mining-induced damage and is an important component of green mining technology [50]. However, the disadvantages of backfill mining, such as higher cost and large backfill requirement, have restricted its wide applications in coal mines.

Considering the time required for the filling body to reach the designed strength and the value of roof displacement before working face is filled. It is generally accepted in the mining industry that the maximum backfill mining height is $4.0 \mathrm{~m}$. The inherent compressibility properties of backfill materials, 
it is impossible to achieve $100 \%$ filling ratio. Considering a filling ratio of $75 \%$, backfill mining is applicable to zones where $M_{c} \geq(1-75 \%) M_{m}$, and the corresponding minimum backfill height is $\left(M_{m}-M_{c}\right) / 75 \%$. The zones which are suitable for the use of backfill mining in Yu-Shen mining area is shown in Figure 18b.

\subsection{Partial Backfill Mining}

In the Yu-Shen mining area, the height of WCFZ at normal areas of a longwall face is about $10-15 \%$ less than that at the open-off cut and the location of first main roof weighting (after 2 to 3 periodic weighting events), as shown in Figure 10. According to the development characteristics of WCFZ, backfill can be carried out around the open-off cut and near the location of first main roof weighting, so to reduce regional stress concentration in the roof and its damage to overburden. As longwall face advances, the consequence of backfill gradually weakens and the stress in the roof will increase again. The partially backfilling at the two above mentioned positions, the roof would collapse more gently than normal face without backfilling, and the roof movement would be in the overall deformation stage.

Partial backfill is able to effectively reduce the heights of WCFZ of the open-off cut zone and the first weighting zone effectively. However, its effect on controlling the development of water conductive fractures is limited when compared with other WCCM methods. Therefore, this method can be used as a supplement to other WCCM methods or adopted in regions with lower water loss risk, such as areas where the height of WCFZ is greater than bedrock thickness but within $15 \%$ of difference.

Therefore, when the sand-soil-bedrock overburden satisfies Equation (10), partial backfill mining should be employed:

$$
\frac{21.75\left(M_{m}-M_{c}\right)+28.28}{21.75 M_{m}+28.28} \leq 15 \%
$$

When the sand-bedrock overburden satisfies Equation (11), partial backfill mining should be employed:

$$
\frac{22.2\left(M_{m}-M_{c}\right)+37.13}{22.2 M_{m}+37.13} \leq 15 \%
$$

When the bedrock overburden satisfies Equation (12), partial backfill mining should be employed:

$$
\frac{16.7\left(M_{m}-M_{c}\right)+30.8}{16.7 M_{m}+30.8} \leq 15 \%
$$

When the soil-bedrock overburden satisfies Equation (13), partial backfill mining should be employed:

$$
\frac{21.97\left(M_{m}-M_{c}\right)+28.42}{21.97 M_{m}+28.42} \leq 15 \%
$$

where, $M_{c}$ denotes the maximum allowable mining height $(\mathrm{m}) ; M_{m}$ is coal thickness $(\mathrm{m})$.

Figure 18c shows the locations suitable for partial backfill mining in Yu-Shen mining area.

\subsection{Narrow Strip Mining}

In narrow strip mining, the block of coal to be mined is divided into strips. After one strip is extracted, the adjacent strip will be left in place to support the overlying strata and the strip next to it will be extracted (similar to drift and pillar mining), as shown in Figure 19. The overburden will thus displace and deform more mildly and evenly than it in the full-seam extraction, maintaining the structural stability of aquicludes during mining, and thereby protecting water resources. However, this method achieves WCCM at the cost of low recovery rate, which is similar to that of height-restricted mining. This is also the main reason restricting its use for water conservation.

In addition, as the coal pillars left to support overburden may fail due to weathering after years of extraction, narrow strip mining is only suitable under certain geological conditions. The recovery of 
coal pillars and the associated safety issues within the goaf are still challenging issues when using narrow strip mining. Therefore, narrow strip mining can be adopted at low-production coal mines with thin seams as long as local conditions permit. Taken into account the current technological and economic conditions and equipment available in the Yu-Shen mining area, narrow strip mining should be a suitable WCCM method for mines with annual production below $0.9 \mathrm{Mt} / \mathrm{a}$ (million tons every year). Figure 18d shows the zones suitable for this method to use within the Yu-Shen mining area. It is worth noting that room and pillar mining has been employed by some local coal mines for many years. This method has two major weaknesses, low recovery rate and non-standard face layout.

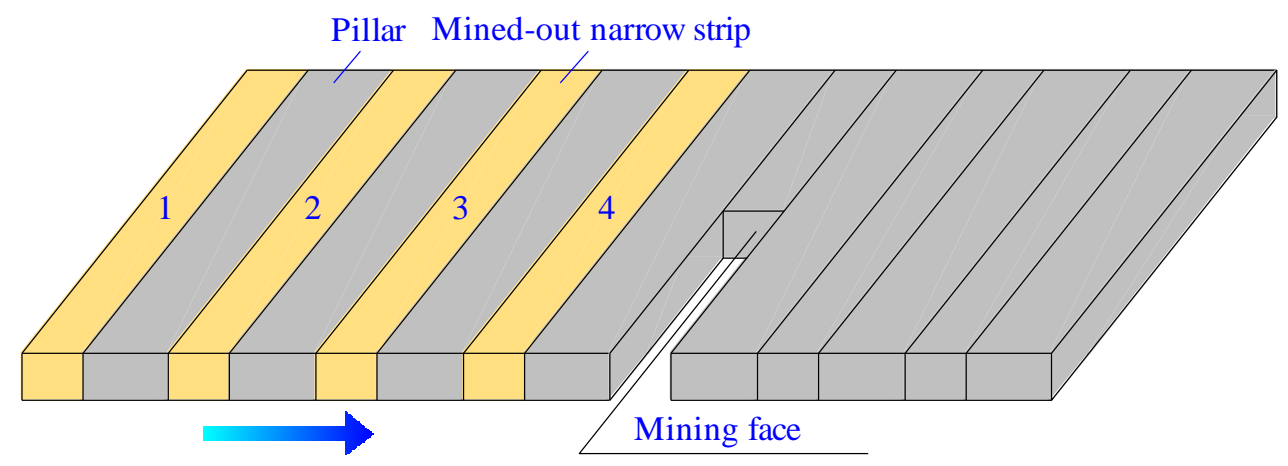

Figure 19. Sketch map of narrow strip mining.

Despite being relatively old-style, narrow strip mining could be an option for some small and medium sized mines to repace the room and pillar mining, whcih can increase recovery rate by over $20 \%$ while also protecting groundwater [7]. This would be particularly useful in coal areas where longwall panels are difficult to design due to adverse geology for example.

\section{Case Studies}

\subsection{Height-Restricted Mining}

The Yushuwan Coal Mine, located in the south of the study area is shown in Figure 18a. It has five minable coal seams and Seam $2^{-2}$ is uppermost and $11 \mathrm{~m}$ thick. The bedrock thickness varies from $85-142 \mathrm{~m}$ and the impermeable soil thickness is around $73-96 \mathrm{~m}$. The mine is categorized into sand-soil-bedrock stratigraphic structure. According to Equation (6), the MAMH was calculated and found between 7-9 $\mathrm{m}$, which is smaller than the actual seam thickness. This indicates that WCCM is needed. Early suggested in Section 6.1, height-restricted mining could be adopted at this mine. Eventually, the actual mining height for the Yushuwan Coal Mine was determined to be $5.5 \mathrm{~m}$. More than five longwall panels have been successfully extracted now with no mining induced WCFZ reaching the overlying Salawusu Formation, demonstrating the achievement of WCCM and local water resource is effectively protected [51].

\subsection{Backfill Mining}

The main seam being mined at the Yuyang Coal Mine is between $2 \mathrm{~m}$ and $4 \mathrm{~m}$ thick. The overlying bedrock is $60 \mathrm{~m}$ to $310 \mathrm{~m}$ thick, and the impermeable soil thickness varies between $15 \mathrm{~m}$ and $120 \mathrm{~m}$. Though this mine is within Yuyang District, Yulin City, its local geology is similar to that of sand-soil-bedrock stratigraphic structure of Yu-Shen mining area due to their geographic proximity (Figure 18b). The MAMH for this mine was calculated using Equation (6) to vary from 3 to $16 \mathrm{~m}$. A comparison with the actual coal thickness suggests that WCCM method needs to be implemented in some parts of mine. The Yuyang coal mine takes eolian sand from the surface as a major component of the paste-like backfill material in order to reduce the backfill cost. At shortwall face 2301, about $5.2 \times 10^{4} \mathrm{~m}^{3}$ of backfill material has been injected into 50 branch roadways, through with the overburden movement and failure were effectively controlled. According to measurements conducted after mining, 
the surface subsidence decreased by over $50 \%$ and the water table declined by less than $1.61 \mathrm{~m}$ on average, implying good water protection effect has been reached [52,53].

\subsection{Narrow Strip Mining}

The Yubujie Coal Mine is a small mine (annual production: $0.3 \mathrm{Mt} / \mathrm{a}$ ) located at the southern boundary of the Yu-Shen mining area (Figure 18d). Seam $2^{-2}$, the uppermost minable seam, is 4-6 $\mathrm{m}$ thick; the overlying bedrock is $90-100 \mathrm{~m}$ thick and impermeable soil is $20-90 \mathrm{~m}$ thick. The mine geology is categorized into soil-bedrock stratigraphic structure. Using Equation (9), the MAMH was estimated to vary between $4-6 \mathrm{~m}$, indicating that WCCM method is needed in some parts of this mine. Given the small size of this mine (with annual production below $0.9 \mathrm{Mt} / \mathrm{a}$ ), narrow strip mining was used. The coal strips mined are $12 \mathrm{~m}$ wide and the coal pillars left unmined are $8 \mathrm{~m}$ wide. This has been used at face 300 and other faces. Field observations demonstrated that the coal pillars were stable and the roof was general intact. The decline of water level in the Salawusu Formation was less than $0.3 \mathrm{~m}$, and the water table remains within $5 \mathrm{~m}$ below surface, demonstrating the effective protection of the local ecological water environment $[7,54-56]$.

\section{Discussion}

(1) AHP is a subjective weighting method. Since the weight used in the present study was mainly provided by scholars for WCCM in Northwest China, further research is needed to confirm whether the weights determined for different influencing factors are applicable to other mining areas.

(2) The proposed equation for the height of WCFZ in the Yu-Shen mining area was only related to mining height, which is similar to the empirical equation provided in the statutory regulations. According to existing empirical and theoretical research, the height of WCFZ induced by coal mining is also significantly affected by several other factors, e.g., overburden structure, roof management method, face length, and burial depth. The relationship between the height of WCFZ and these factors is nonlinear and hard to quantify. At present, no research has provided satisfactory quantitative results about the mechanisms and levels of their influences on the height of caved and fractured zones. Field production practice suggests that when a face is short (e.g., less than $50 \mathrm{~m}$ ), the overburden can form a self-balancing arch and face length has limited influence on the height of WCFZ. Under subcritical mining condition, the height of WCFZ tends to increase with the increase of face length. Under critical mining condition, it continues to increase with the increase of face length, but the rate of increase is relatively low, and the vertical extension of this zone will basically terminate at a particular height. In terms of the relationship between the height of WCFZ and mining depth, it is found that in-situ stress rises with the increase of mining depth within a certain mining depth, and the zone of stress-relief horizontal fractures in roof strata will also expand vertically. When mining reaches a certain depth, the height of WCFZ will not increase with the increase of mining depth. This can be attributed to the high horizontal in-situ stress which could force the mining-induced stress-relief fractures to close rapidly. The data used to investigate the impact of advance rate on the height of WCFZ were generally collected two months after the face passing by. As a result, by the time of measurement, the overburden strata displacement had already become stable and the WCFZ had basically stopped developing in the vertical direction. Therefore, the results of the regression analysis based on the measurements could not reflect the actual impact of advance rate on the height of WCFZ. Under the specific geological conditions of the Yu-Shen mining area (including structure of overburden and mining depth) and mining method (including roof management method and face length), the height of WCFZ depends heavily on mining height. In addition, the coefficients in the proposed Equation also take into account the effects of overburden structure, roof management method, face length, and mining depth on WCFZ height. Thus, it is reasonable in study to derive the equation of WCFZ height by regression analysis only based on mining heights. This Equation can provide a scientific basis for WCCM, preventing water percolating from roof in Yu-Shen mining area. 
(3) The applicability of different WCCM methods was determined based on the specific geological conditions of the Yu-Shen mining area together with the available equipment and techniques. For example, height-restricted mining is suitable for regions where the currently used mining equipment can still be used even after imposing a height limit on it (MAMH $>2 \mathrm{~m}$ ). Backfill mining is applicable to zones where the effective mining height (i.e., the mining height minus the height of compacted backfill) satisfies the requirement of WCCM (filling ratio $=75 \%$ ). Partial backfill mining is applicable to zones where the difference between the actual height of WCFZ and its theoretical value required for water conservation is smaller than $15 \%$. When applied to other mining areas in Northwest China, the criteria for zoning based on applicability of WCCM methods used in this study should be properly adjusted according to specific geological conditions.

(4) From a technical perspective, each WCCM method has its own limitations and none of them can be applied individually to the entire mining area. In terms of applicability, backfill mining and height-restricted mining have the widest applicability, followed by partial backfill mining, and narrow strip mining has the least. Considering the low recovery rate associated with height-restricted mining, priority should be given to backfill mining when conditions apply. The applicability zones of each method are compatible with each other rather than mutually exclusive, there are overlaps between the zones suitable for different methods. The optimal WCCM method for the overlap areas should be determined with due consideration of personnel, equipment, and techniques available. Multiple WCCM methods can be used together in order to maximize economic benefits while protecting water resources. For instance, after narrow strip mining, backfill mining can be used to recover the coal pillars left. The combination of these two methods can control the development of water conductive fractures while improving coal recovery rate.

\section{Conclusions}

(1) A four-level AHP model was constructed to evaluate the influencing factors of WCCM and the weight of each influencing factor was obtained. The results show that: the overburden thickness, stratigraphic structure, the aquifer thickness, aquiclude thickness and the effective mining height are the most important factors among all influencing factors. These five most important factors are plotted as "five maps", forming the basis for studying WCCM in the Yu-Shen mining area.

(2) Based on the theory analysis, field measurements and numerical simulation results, the equations were developed to predict the mining-induced heights of caved zone, WCFZ and the thickness of protective zone in the mining area. Thus three contour maps of the height of these "three zones" across the Yu-Shen mining area were obtained.

(3) Based on the temporal and spatial relationship between measured bedrock thickness, soil strata thickness, heights of caved zone and WCFZ induced by mining, and the thickness of protective zone, the criterion for determining the impact of coal mining on groundwater were proposed. According to this criterion, the Yu-Shen mining area was divided into six partitions, including extremely severe impacted zone, severe impacted zone, moderate impacted zone, slight impacted zone, unaffected impacted zone and unconfirmed zone.

(4) If the thickness of soil strata plus the thickness of bedrock is greater than the height of WCFZ plus the height of protective zone, then the WCCM can be realized. Subtracting the necessary thickness of protective zone from the total thickness of soil and bedrock yields the height of WCFZ. The maximum allowable mining height (MAMH) for successful WCCM was determined by back calculation, and a contour map of MAMH was drawn for the Yu-Shen mining area.

(5) The case studies proved that applicability partition of different WCCM methods, including height-restricted mining, (partial) backfilling and narrow strip mining, was a reliable tool to guide future mining in the coal area. 
(6) Based on this research, it can be concluded that a "five maps, three zones and two zoning plans" approach can be used in other coal mining regions in Northwest China, to optimize mining whilst limiting water disruption above the mining area.

Author Contributions: Y.X. conceived the research and wrote the original draft. L.M. revised and reviewed the manuscript. Y.Y. collected the borehole data. All authors have read and agreed to the published version of the manuscript.

Funding: The Fundamental Research Funds for the Central Universities (2017XKQY096); the Priority Academic Program Development of Jiangsu Higher Education Institutions.

Acknowledgments: This work was supported by the Fundamental Research Funds for the Central Universities (2017XKQY096), and the Priority Academic Program Development of Jiangsu Higher Education Institutions.

Conflicts of Interest: The authors declare that they have no competing financial interests in connection with the work submitted.

\section{References}

1. Gu, D.Z. Theory framework and technological system of coal mine underground reservoir. J. China Coal Soc. 2015, 40, 239-246.

2. Ma, L.; Jin, Z.; Liang, J.; Sun, H.; Zhang, N.; Li, P. Simulation of water resource loss in short-distance coal seams disturbed by repeated mining. Environ. Earth Sci. 2015, 74, 5653-5662. [CrossRef]

3. Meng, Z.; Shi, X.; Li, G. Deformation, failure and permeability of coal-bearing strata during longwall mining. Eng. Geol. 2016, 208, 69-80. [CrossRef]

4. Wang, L.; Mu, Y.; Zhang, Q.; Zhang, X. Groundwater use by plants in a semi-arid coal-mining area at the Mu Us Desert frontier. Environ. Earth Sci. 2012, 69, 1015-1024. [CrossRef]

5. Yin, L.; Hou, G.; Dou, Y.; Tao, Z.; Li, Y. Hydrogeochemical and isotopic study of groundwater in the Habor Lake Basin of the Ordos Plateau, NW China. Environ. Earth Sci. 2009, 64, 1575-1584. [CrossRef]

6. Adhikary, D.; Guo, H. Modelling of longwall mining-induced strata permeability change. Rock Mech. Rock Eng. 2014, 48, 345-359. [CrossRef]

7. Booth, C. Groundwater as an environmental constraint of longwall coal mining. Environ. Earth Sci. 2006, 49, 796-803. [CrossRef]

8. Booth, C.J. Confined-unconfined changes above longwall coal mining due to increases in fracture porosity. Environ. Eng. Geosci. 2007, 13, 355-367. [CrossRef]

9. Fan, G.; Zhou, L. Mining-induced variation in water levels in unconsolidated aquifers and mechanisms of water preservation in mines. Min. Sci. Technol. (China) 2010, 20, 814-819. [CrossRef]

10. Gale, W.J. Aquifer Inflow Prediction above Longwall Panels, ACARP End of Grant Report; ACARP: Brisbane, Australia, 2008; C13013; p. 96.

11. Li, Y. Groundwater system for the periods of pre- and post-longwall mining over thin overburden. Int. J. Min. Reclam. Environ. 2015, 30, 295-311. [CrossRef]

12. Ma, L.Q.; Sun, H.; Wang, F.; Li, J.M.; Jin, Z.Y.; Zhang, W. Analysis of the ground water level change of aquifer-protective mining in longwall coalface for shallow seam. J. Min. Saf. Eng. 2014, 31, 232-235.

13. Majdi, A.; Hassani, F.P.; Nasiri, M.Y. Prediction of the height of destressed zone above the mined panel roof in longwall coal mining. Int. J. Coal Geol. 2012, 98, 62-72. [CrossRef]

14. Fan, L.M. Discussing on coal mining under water-containing condition. Coal Geol. Explor. 2005, 33, 50-53.

15. Fan, L.M. Scientific connotation of water-preserved mining. J. China Coal. Soc. 2017, 42, 27-35.

16. Qian, M.G.; Xu, J.L.; Wang, J.C. Further on the sustainable mining of coal. J. China Coal Soc. 2018, 43, 1-13.

17. Zhang, S.; Fan, G.; Liu, Y.; Ma, L. Field trials of aquifer protection in longwall mining of shallow coal seams in China. Int. J. Rock Mech. Min. Sci. 2010, 47, 908-914. [CrossRef]

18. Karaman, A.; Akhiev, S.S.; Carpenter, P.J. A new method of analysis of water-level response to a moving boundary of a longwall mine. Water Resour. Res. 1999, 35, 1001-1010. [CrossRef]

19. Shultz, R. Ground-water hydrology of Marshall County, West Virginia, with emphasis on the effects of longwall coal mining. Water Resour. Investig. Rep. 1988. [CrossRef]

20. Booth, C.J.; Spande, E.D.; Pattee, C.T.; Miller, J.D.; Bertsch, L.P. Positive and negative impacts of longwall mine subsidence on a sandstone aquifer. Environ. Earth Sci. 1998, 34, 223-233. [CrossRef] 
21. Hill, J.G.; Price, D.R. The impact of deep mining on an overlying aquifer in western pennsylvania. Ground Water Monit. Remediat. 1983, 3, 138-143. [CrossRef]

22. Robertson, J. Challenges in sustainably managing groundwater in the Australian Great Artesian Basin: Lessons from current and historic legislative regimes. Hydrogeol. J. 2019, 28, 343-360. [CrossRef]

23. Howladar, M.F. Coal mining impacts on water environs around the Barapukuria coal mining area, Dinajpur, Bangladesh. Environ. Earth Sci. 2012, 70, 215-226. [CrossRef]

24. Gandhe, A.; Venkateswarlu, V.; Gupta, R.N. Extraction of coal under a surface water body-A strata control investigation. Rock Mech. Rock Eng. 2005, 38, 399-410. [CrossRef]

25. Fan, L.M.; Xiang, M.X.; Peng, J.; Li, C.; Li, Y.H.; Wu, B.Y.; Bian, H.Y.; Gao, S.; Qiao, X.Y. Groundwater response to intensive mining in ecologically fragile area. J. China Coal Soc. 2016, 41, 2672-2678.

26. Wang, S.M.; Huang, Q.X.; Fan, L.M.; Yang, Z.Y.; Shen, T. Study on overburden aquiclude and water protection mining regionazation in the ecological fragile mining area. J. China Coal Soc. 2010, 35, 7-14.

27. Miao, X.X.; Chen, R.H.; Bai, H.B. Fundamental concepts and mechanical analysis of water resisting key strata in water preserved mining. J. China Coal Soc. 2017, 32, 561-564.

28. Huang, Q.X. Research on roof control of water conservation mining in shallow seam. J. China Coal Soc. 2017, $42,50-55$.

29. Zhang, D.S.; Li, W.P.; Lai, X.P.; Fan, G.W.; Liu, W.Q. Development on basic theory of water protection during coal mining in northwest of China. J. China Coal Soc. 2017, 42, 36-43.

30. Ma, L.Q.; Zhang, D.S.; Dong, Z.Z. Evolution mechanism and process of aquiclude fissures. J. Min. Saf. Eng. 2011, 28, 340-344.

31. Ma, L.Q.; Cao, X.Q.; Liu, Q.; Zhou, T. Simulation study on water-preserved mining in multi-excavation disturbed zone in close-distance seams. Environ. Eng. Manag. J. 2013, 12, 1849-1853. [CrossRef]

32. Ma, L.Q.; Du, X.; Wang, F.; Liang, J.M. Water-preserved Mining Technology for Shallow Buried Coal Seam in Ecologically-vulnerable Coal field: A case study in the Shendong Coal field of China. Disaster Adv. 2013, 6, 268-278.

33. Wang, A.; Ma, L.; Wang, Z.; Zhang, D.; Li, K.; Zhang, Y.; Yi, X. Soil and water conservation in mining area based on ground surface subsidence control: Development of a high-water swelling material and its application in backfilling mining. Environ. Earth Sci. 2016, 75, 779. [CrossRef]

34. Li, M.; Zhang, J.; Huang, P.; Gao, R. Mass ratio design based on compaction properties of backfill materials. J. Cent. South. Univ. 2016, 23, 2669-2675. [CrossRef]

35. Wu, Q. Progress, problems and prospects of prevention and control technology of mine water and reutilization in China. J. China Coal Soc. 2014, 39, 795-805.

36. Zhang, D.S.; Liu, H.L.; Fan, G.W.; Wang, X.F. Connotation and prospection on scientific mining of large Xinjiang coal base. J. Min. Saf. Eng. 2015, 32,1-6.

37. Zhang, S.; Fan, G.; Ma, L.; Wang, X. Aquifer protection during longwall mining of shallow coal seams: A case study in the Shendong Coalfield of China. Int. J. Coal Geol. 2011, 86, 190-196. [CrossRef]

38. Li, W.P.; Ye, G.J.; Zhang, L.; Duan, Z.H.; Zhai, L.J. Study on the engineering geological conditions of protected water resources during coal mining action in Yu-Shen Mine Area in the North Shanxi Province. J. China Coal Soc. 2000, 25, 449-454.

39. Du, J.P.; Meng, X.R. Mining Science; China University of Mining and Technology Press: Xuzhou, China, 2014.

40. Peng, S.Y. Coal Mine Ground Control; China University of Mining and Technology Press: Xuzhou, China, 2013.

41. Sui, W.; Hang, Y.; Ma, L.; Wu, Z.; Zhou, Y.; Long, G.; Wei, L. Interactions of overburden failure zones due to multiple-seam mining using longwall caving. Bull. Int. Assoc. Eng. Geol. 2014, 74, 1019-1035. [CrossRef]

42. Miao, J.K.; Jiang, Z.Q. Research on the height of water flowing fractured zone in the fully mechanized mining face by drilling exploration. Shaanxi Coal 2014, 33, 33-36.

43. Wei, J.C.; Wu, F.Z.; Xie, D.L.; Yin, H.Y.; Guo, J.B.; Xiao, L.L. Development characteristic of water flowing fractured zone under semi-cemented medium-low strength country rock. J. China Coal Soc. 2016, 41, 974-983.

44. Yin, S.X.; Xu, B.; Xu, H.; Xia, X.X. The research on the height of the "Two zones" in Zhuozishan coalfield. Disaster Adv. 2013, 6, 78-84.

45. Gao, B.B.; Liu, Y.P.; Pan, J.Y.; Yuan, T. Detection and analysis of height of water flowing fractured zone in underwater mining. Chin. J. Rock Mech. Eng. 2014, 33, 3384-3390.

46. Huang, H.F.; Yan, Z.G.; Yao, B.H.; Xu, H.J. Research on the process of fracture development in overlying rocks under coal seams group mining in Wanli mining area. J. Min. Saf. Eng. 2012, 29, 619-624. 
47. Wang, F.; Tu, S.; Zhang, C.; Zhang, Y.; Bai, Q. Evolution mechanism of water-flowing zones and control technology for longwall mining in shallow coal seams beneath gully topography. Environ. Earth Sci. 2016, 75, 1309. [CrossRef]

48. $\mathrm{Xu}, \mathrm{Y} . \mathrm{C}$. Design methods of the effective water-resisting thickness for the protective seam of the water barrier in fully-caving mechanized coalmining. J. China Coal Soc. 2005, 30, 305-308.

49. Fan, L.M.; Ma, X.D.; Ji, R.J. The progress of research and engineering practice of water-preserved coal mining in western eco-environment frangible area. J. China Coal Soc. 2015, 40, 1711-1717.

50. Qian, M.G.; Miao, X.X.; Xu, J.L. Green mining of coal resources harmonizing with environment. J. China Coal Soc. 2007, 32, 1-7.

51. Shi, B.Q. Research on water-preserved-mining in shallow seam covered with rock soil and sand in Northern Shaanxi. J. Min. Saf. Eng. 2011, 28, 548-552.

52. Lv, W.H. The application of the backfill mining in Yu-yang coal area. Sci. Technol. Innov. Her. 2013, 33, 48-50.

53. Wang, W.X.; Sui, W.; Faybishenko, B.; Stringfellow, W. Permeability variations within mining-induced fractured rock mass and its influence on groundwater inrush. Environ. Earth Sci. 2016, 75, 326. [CrossRef]

54. Chi, M.; Zhang, D.; Liu, H.; Wang, H.; Zhou, Y.; Zhang, S.; Yu, W.; Luang, S.; Zhao, Q. Simulation analysis of water resource damage feature and development degree of mining-induced fracture at ecologically fragile mining area. Environ. Earth Sci. 2019, 78, 88. [CrossRef]

55. Lu, Y.; Wang, L. Numerical simulation of mining-induced fracture evolution and water flow in coal seam floor above a confined aquifer. Comput. Geotech. 2015, 67, 157-171. [CrossRef]

56. Hollá, L.; Buizen, M. The ground movement, strata fracturing and changes in permeability due to deep longwall mining. Int. J. Rock Mech. Min. Sci. Géoméch. Abstr. 1991, 28, 207-217. [CrossRef]

(C) 2020 by the authors. Licensee MDPI, Basel, Switzerland. This article is an open access article distributed under the terms and conditions of the Creative Commons Attribution (CC BY) license (http://creativecommons.org/licenses/by/4.0/). 